\title{
Patterns of aquatic decay and disarticulation in juvenile Indo-Pacific crocodiles (Crocodylus porosus), and implications for the taphonomic interpretation of fossil crocodyliform material
}

\author{
Caitlin E. Syme* \\ caitlin.syme@uqconnect.edu.au
}

Steven W. Salisbury

School of Biological Sciences, The University of Queensland, Brisbane, QLD 4072, Australia

•Corresponding author. Tel.: + 61733651398.

\begin{abstract}
High levels of skeletal articulation and completeness in fossil crocodyliforms are commonly attributed to rapid burial, with decreasing articulation and completeness thought to result from prolonged decay of soft tissue and the loss of skeletal connectivity during 'bloat and float'. These interpretations are based largely on patterns of decay in modern mammalian and avian dinosaur carcasses. To address this issue, we assessed the decay of buried and unburied juvenile Crocodylus porosuscarcasses in a controlled freshwater setting. The carcasses progressed through typical vertebrate decay stages (fresh, bloated, active decay, and advanced decay), reaching the final skeletal stage on average 56 days after death. Unburied carcasses commenced floating five days post-mortem during the bloated stage, and one buried carcass only commenced floating 12 days post-mortem. While floating, skeletal elements remained articulated within the still coherent dermis, except for thoracic ribs, ischia and pubic bones. The majority of disarticulation occurred at the sediment-_water interface after the carcasses sank during the advanced decay stage, $\sim 36$ days post-mortem. Based on these results we conclude that fossil crocodyliform specimens displaying high levels of articulation are not the result of prolonged subaerial and subaqueous decay in a low-energy, aqueous environment. Using extant juvenile $C$. porosus as a proxy for fossil crocodyliforms, rapid burial in an aquatic setting would have to occur prior to the carcass floating, and would also have to continually negate the positive buoyancy associated with bloating. Rapid burial does not have to be the only avenue to preservation of articulation, as other mechanisms such as physical barriers and internal physiological chemistry could prevent carcasses from floating and subsequently disarticulating upon sinking. The inference that a large proportion of skeletal elements could drift from floating carcasses in a
\end{abstract}


low energy setting with minimal scavenging, thereby causing a loss of completeness, seems unlikely.

Keywords: Taphonomy; Crocodyliform; Disarticulation; Decay experiment;Actuopalaeontology

\section{Introduction}

Fossil crocodyliforms are ubiquitous in Mesozoic and Cenozoic aquatic sedimentary units worldwide (Kuhn, 1936; Steel, 1973; Buffetaut, 1982; Benton and Clark, 1988; Clark, 1994; Markwick, 1998; Rauhut and Lopez-Arbarello, 2008; Pol et al., 2009), owing both to their semi-aquatic lifestyle and the predisposition of aquatic depositional settings to preserve organic material. For fossil crocodyliforms, taphonomic research has focused on documenting patterns of articulation, completeness, and types of tissue preserved for individual specimens (Grange and Benton, 1996; Salisbury et al., 2003; Schwarz-Wings et al., 2011; de Araújo and da Silva Marinho, 2013), and the application of semi-quantitative scores to qualitative characters such as degree of skeletal articulation and completeness for multiple specimens (Beardmore et al., 2012a,b). Understanding the processes that cause preburial taphonomic signatures is crucial for reconstructing aspects of the ecosystem, depositional settings and preservational regime in which crocodyliform remains are preserved. Preservation of articulated crocodyliform fossils is often attributed to rapid burial, with decreasing degrees of articulation attributed to increasing subaerial and subaqueous decay via taphonomic processes such as endogenous decay (necrolysis) and scavenging, erosion, and transport in high-energy aqueous environments (biostratinomy) (Salisbury et al., 2003; Beardmore et al., 2012a,b; de Araújo and da Silva Marinho, 2013). These inferences often rely on analogical reasoning: for example, in Beardmore et al.'s (2012b) model, basic assumptions about crocodyliform decay are based on published accounts of decay in extant mammals and avian dinosaurs, including loss of completeness as a result of disarticulation during 'bloat and float' - - where decay via endogenous bacteria creates gas and causes the carcasses to bloat, and if located in a body of water, float to the water's surface and decay subaerially (Schafer and Craig, 1972; Davis and Briggs, 1998; Rogers and Kidwell, 2007). Thus far, actualistic taphonomic studies using extant crocodyliforms are yet to be utilized in the interpretation of taphonomic processes associated with the preservation of fossil crocodyliform specimens. This is due to the scarcity of actualistic taphonomic experiments for extant crocodyliforms: those studies that have been conducted do not focus on patterns of decay, or decay in an aquatic setting, but instead on (1) insect succession patterns on carcasses decaying 
in a terrestrial setting (Watson and Carlton, 2005, 2003; Nelder et al., 2009), (2) the effect of burial on bone (Abdel-Maksoud and Abdel-Hady, 2011), (3) biofilm formation on bone (Peterson, 2010), or (4) forensic herpetology for criminal cases (Cooper, 2008; Frye, 2008; Rothschild, 2009).

The benefit of actualistic taphonomy is that the time taken to progress through the five stages of vertebrate decay-_ (1) fresh, (2) bloated, (3) active decay, (4) advanced decay, and (5) remains (modified from Payne, 1965; Anderson and Hobischak, 2004; Cambra-Moo et al., 2008)__ a along with the level of skeletal articulation during these five stages, can be observed in real time, providing an "...empirical database of cause (taphonomic process) and effect (preservational bias)" (Allison et al., 1991, p. 78). A combination of relational analogies and actualistic taphonomy have been successfully used to interpret the taphonomic histories of fossil fish (Elder and Smith, 1984; Elder, 1985; Elder et al., 1988; Hellawell and Orr, 2012; Iniesto et al., 2013), reptiles (Brand et al., 2003a,b; Beardmore et al., 2012a,b; Meyer, 2012; Richter and Wuttke, 2012; Smith and Wuttke, 2012), mammals (Weigelt, 1989; Brand et al., 2003b; Noto, 2009; Behrensmeyer and Miller, 2012; Schwermann et al., 2012), and avian dinosaurs (Davis and Briggs, 1998; Brand et al., 2003b; Cruz, 2007; Faux and Padian, 2007; Prassack, 2011). Even with the potential pitfalls of assuming taphonomic uniformitarianism (see discussion in Gifford, 1981; Elder et al., 1988; Brasier et al., 2011), actualistic taphonomy can provide a more powerful analytical tool than analogical reasoning alone (Young, 1989; Allison et al., 1991; Denys, 2002; Noto, 2009). By increasing lines of evidence through the combination of relational analogies and actualistic taphonomy, the accuracy of interpretations regarding various aspects of ancient taphonomic processes and depositional environments can be increased (Gifford-Gonzalez, 1991).

The purpose of this investigation was to record typical patterns of decay in extant crocodyliforms in an aquatic setting, and the impact of rapid burial on articulation, using juvenile Crocodylus porosus carcasses. Through a short-term controlled actualistic decay experiment, our goal was to (1) identify and create a visual guide to the typical decay stages that extant crocodyliform carcasses progress through, and record the timeframe of each decay stage, (2) record the patterns of decay and disarticulation while carcasses float, (3) determine if skeletal articulation of a carcass decaying in a low-energy fresh water setting could mimic the skeletal articulation preserved in a rapidly buried carcass, and (4) explore the application of decay and disarticulation data to fossil crocodyliform taphonomic interpretation. 


\section{Materials and methods 2.1 Experiment location}

The experiment took place between September 2012 and February 2013 during Brisbane-'s sub-tropical spring-_summer. The experiment was situated in the UQ Palaeontology Lab open-air storage and preparation facility, in St Lucia, Brisbane, Australia (hereafter referred to as the 'study site'). Although the study site was located within a roofed pen which limited the amount of solar radiation affecting carcasses, it allowed for minimal influence of precipitation, which was deemed more likely to affect water quality and, potentially, change decomposition patterns.

\subsection{Treatments}

Three (3) treatments were designed for this experiment, to observe the rate of decay and disarticulation of crocodile carcasses compared with the rate at which carcasses are buried. All carcasses were placed in water filled aquaria after one day post-mortem. For Treatments 1 and 2 (see following description), sand was added to the water filled aquaria to simulate rapid burial in an aquatic environment. The water levels in these aquaria were then maintained by gently topping up the water once a fortnight using hose fitted with a fine shower nozzle so as not to disturb the carcasses, or in the case of buried carcasses, the overlying sand (2-3 cm of water above the sand layer was present for the duration of the decay experiment). These treatments are detailed below:

Treatment 1: Carcasses were buried under a $20 \mathrm{~cm}$ thick layer of fine-grained sand. This simulated a rapid burial scenario.

Treatment 2: Carcasses were allowed to 'bloat and float' and decay subaerially. Once all parts of the carcass had sunk, they were gently covered in a $20 \mathrm{~cm}$ layer of fine-grained sand.

Treatment 3: Carcasses were allowed to 'bloat and float' and decay subaerially. Once the carcasses had sunk, they were left undisturbed to decay subaqueously with no burial under fine-grained sand.

These treatments simulated 'best case scenarios' for subaerial and subaqueous decay under rapid burial and low energy environmental conditions in an aquatic setting. No current was induced in any of the aquaria in order to ensure that 
patterns of disarticulation observed at the end of the experiment were not a result of water movement.

\subsection{Specimens}

Eight male juvenile Indo-Pacific crocodile carcasses (Crocodylus porosus) were sourced from a previous experiment investigating influence of diet on bone growth and the isotopic composition of tissues. During the previous experiment these animals were initially fed either chicken (Gallus gallus domesticus) and kangaroo (Macropus sp.) mince supplemented with ProVet multivitamin supplement, or half chicken/kangaroo mix and half minced mullet (Mugil cephalus). In the final six months leading up to euthanasia all the animals were fed chicken and kangaroo meats supplemented with beef (Bos primigenius), mullet, and whole dayold chicks, and Wombaroo Reptile Supplement. On the 18th of September 2012, the $C$. porosus were euthanized via thiopental sodium $(1 \mathrm{~mL} / \mathrm{kg})$ administered intravenously into the cervical sinus, after which breathing stopped immediately. Final weight and morphometric measurements were taken within an hour after death. The previous experimental conditions were deemed unlikely to have influenced the subsequent decay sequences, excluding, perhaps, post-mortem sampling that involved an incision through the right dorsal femoral muscles and removal of femoral bone mid-shaft at the caudal depression (the assumed attachment point for the m. adductor femoris in crocodilians; see Brochu, 1992; Klein et al., 2009). As all individuals underwent the same procedure on the right femur, and the left femur remained intact on each individual, the observations drawn from decay patterns in limbs would focus on the left and right forelimbs and left hindlimb. Carcasses were refrigerated overnight, remained unfrozen, and allowed to reach ambient air temperature 2 hoursh prior to the commencement of experiment. Each crocodile carcass was randomly allocated the following treatment numbers: $\mathrm{CR} 1 \mathrm{~A},-\_1 \mathrm{~B},--2 \mathrm{~A},--2 \mathrm{~B},--2 \mathrm{C},-\_3 \mathrm{~A},-{ }_{-3} \mathrm{~B}, \quad$ and $-3 \mathrm{C}$ : where ' $\mathrm{CR}$ ' denotes a crocodilian carcass, ' $1-3$ ' denotes the treatment number (described below), and'A$\mathrm{C}$ ' denotes an individual within each treatment. The pre-mortem length, weight, and diet of each individual are shown in Table 1.

Table 1 Pre-mortem lengths, weights, and diet of each juvenile CrocodylusC.porosusmeasured on the 18th September 2012.

$\begin{array}{cc}\text { Specimen } & \text { Mass } \\ (\mathrm{kg})\end{array}$
Length measurements in $\mathrm{mm}$

$\begin{array}{rcccccccc}\text { Total } & \text { Snout- } & \text { SVL } & \text { SVL } & \text { Head } & \text { Snout- } & \text { Inter- } & \text { Head } & \text { Cranial } \\ \text { length } & \begin{array}{c}\text { vent } \\ \text { length }\end{array} & \begin{array}{c}\text { cranial } \\ \text { terminal }\end{array} & \begin{array}{c}\text { length } \\ \text { lenital }\end{array} & \begin{array}{c}\text { eye } \\ \text { length }\end{array} & \text { distance } & \text { width } & \begin{array}{c}\text { platform } \\ \text { width }\end{array}\end{array}$




\begin{tabular}{|c|c|c|c|c|c|c|c|c|c|c|}
\hline \multirow[t]{2}{*}{ Specimen } & \multirow{2}{*}{$\begin{array}{c}\text { Mass } \\
(\mathrm{kg})\end{array}$} & \multicolumn{9}{|c|}{ Length measurements in $\mathrm{mm}$} \\
\hline & & $\begin{array}{l}\text { Total } \\
\text { length }\end{array}$ & $\begin{array}{c}\text { Snout- } \\
\text { vent } \\
\text { length }\end{array}$ & $\begin{array}{c}\text { SVL } \\
\text { cranial } \\
\text { C1 }\end{array}$ & $\begin{array}{c}\text { SVL } \\
\text { terminal } \\
\text { C1 }\end{array}$ & $\begin{array}{l}\text { Head } \\
\text { length }\end{array}$ & $\begin{array}{l}\text { Snout- } \\
\text { eye } \\
\text { length }\end{array}$ & $\begin{array}{c}\text { Inter- } \\
\text { orbital } \\
\text { distance }\end{array}$ & $\begin{array}{l}\text { Head } \\
\text { width }\end{array}$ & $\begin{array}{l}\text { Cranial } \\
\text { platform } \\
\text { width }\end{array}$ \\
\hline CR1A & 1.83 & 827 & 397 & 385 & 397 & 116.3 & 69.13 & 6.87 & 53.49 & 30.84 \\
\hline CR1B & 2.29 & 914 & 446 & 433 & 444 & 130.59 & 79.11 & 6.97 & 58.81 & 34.79 \\
\hline CR2A & 1.65 & 810 & 393 & 379 & 390 & 114.68 & 67.68 & 7.11 & 52.76 & 32.75 \\
\hline CR2B & 1.46 & 812 & 386 & 371 & 381 & 117.08 & 69.29 & 5.33 & 51.24 & 30.54 \\
\hline $\mathrm{CR} 2 \mathrm{C}$ & 1.65 & 877 & 423 & 408 & 418 & 116.62 & 69.33 & 6.97 & 54.05 & 31.22 \\
\hline CR3A & 2.28 & 894 & 435 & 422 & 434 & 126.41 & 77.33 & 7.7 & 58.56 & 34.76 \\
\hline CR3B & 2.05 & 900 & 442 & 423 & 436 & 127.45 & 77.38 & 7.88 & 57.92 & 35.22 \\
\hline CR3C & 2.09 & 870 & 422 & 414 & 425 & 121.95 & 71.68 & 5.97 & 54.97 & 33.34 \\
\hline
\end{tabular}

\subsection{Methods}

Five glass aquaria with glass partitions (totaling 10 aquaria, eight of which were used for the experiment, each $140 \mathrm{~L}$ in capacity, $0.9 \mathrm{~m}$ long, $0.4 \mathrm{~m}$ wide and $0.4 \mathrm{~m}$ high) were placed at the study site. Each aquarium was filled with a $10 \mathrm{~cm}$ deep layer of very fine to fine-grained quartz sand. The aquaria were then filled with tap water (approximately 90 L). A YSI Model 85 Handheld water quality probe and a Eutech Ecoscan $\mathrm{pH}_{5 / 6}$ meter were used to record water temperature, $\mathrm{pH}$, conductivity, salinity, and dissolved oxygen prior to carcass addition (see Table 2). Aluminium mesh wire was laid across the top of each aquarium to prohibit access to carcasses by macro-scavengers, but still allowed access for micro-scavengers (predominantly flying insects).

Table 2 Water quality of each vessel (named after each Crocodylus porosus specimen) prior to carcass addition. Two water quality instruments were used: a Eutech Ecoscan pH 5/6 meter, and a YSI Model 85 Handheld probe.

\begin{tabular}{|c|c|c|c|c|c|c|}
\hline \multirow[t]{2}{*}{ Vessel } & \multirow[t]{2}{*}{ Date } & \multicolumn{2}{|c|}{ Eutech Ecoscan pH 5/6 meter } & \multicolumn{3}{|c|}{ YSI Model 85 Handhelc } \\
\hline & & $\begin{array}{c}\text { Temperature } \\
\left({ }^{\circ} \mathrm{C}\right)\end{array}$ & $\mathrm{pH}$ & $\begin{array}{c}\text { Temperature } \\
\left({ }^{\circ} \mathrm{C}\right)\end{array}$ & $\begin{array}{l}\text { Conductivity } \\
\qquad(\mathrm{m} / \mathrm{S})\end{array}$ & $\begin{array}{c}\text { Salinity } \\
\text { (ppt) }\end{array}$ \\
\hline CR1A & $\begin{array}{l}\text { Day } 1-\overline{-} \\
19 / 09 / 2012\end{array}$ & 21.2 & 7.73 & 20.9 & 0.462 & \\
\hline CR1B & $\begin{array}{l}\text { Day } 1-\overline{-} \\
19 / 09 / 2012\end{array}$ & 21.3 & 7.55 & 20.2 & 0.46 & \\
\hline
\end{tabular}




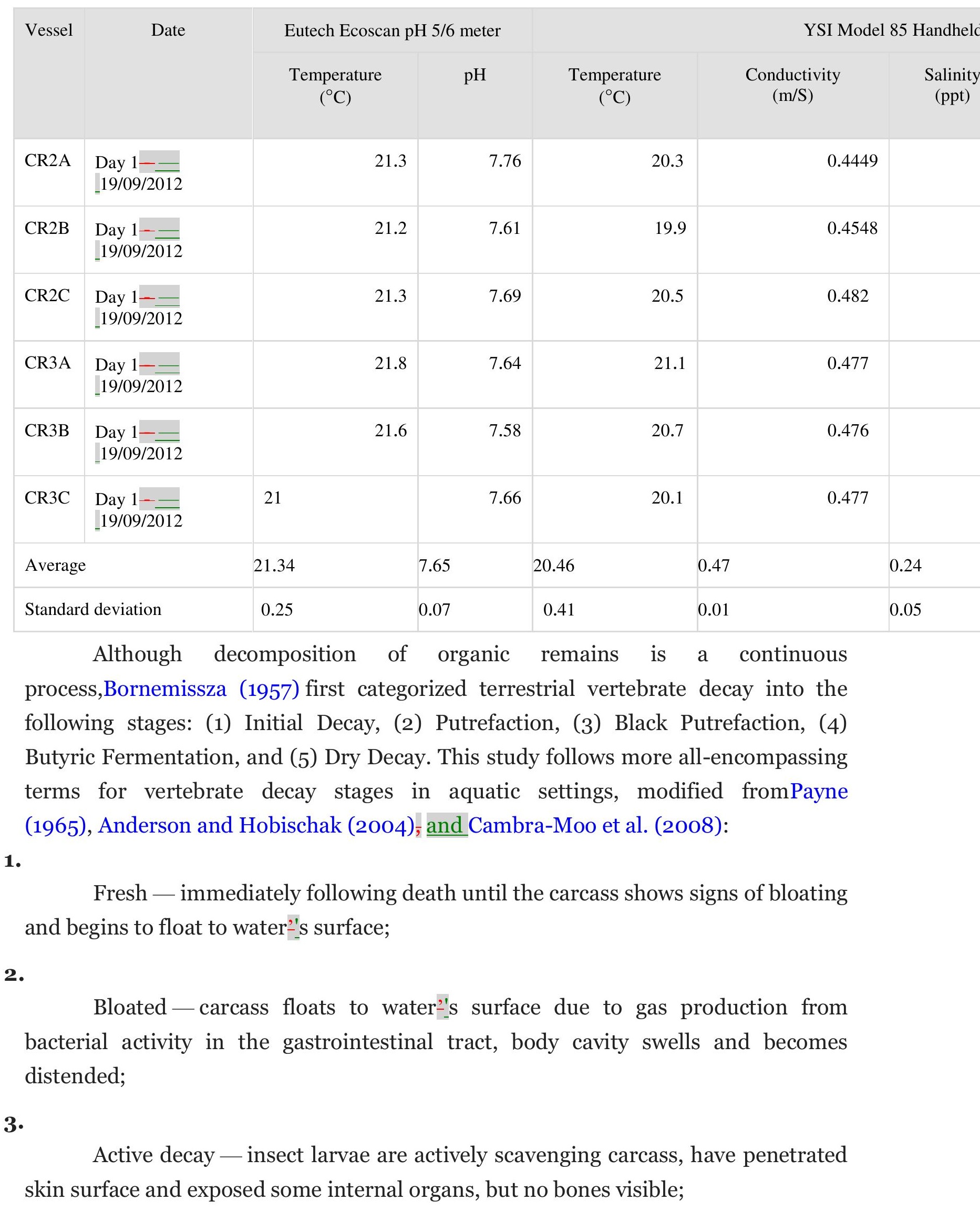

4. 
Advanced decay - first bones are exposed. Eventually internal organs are penetrated, resulting in the release of gases. The carcass sinks. Decay continues underwater from aquatic organisms, with less than one half of the skeleton exposed;

$5 \cdot$

Remains - majority of flesh has been removed exposing more than one half of the skeleton. Very few scavengers remain.

These observable decay stages for Treatment 2 and Treatment 3 crocodile carcasses (CR2A, $-\_2 \mathrm{~B},-\_-2 \mathrm{C}$, and $-\_3 \mathrm{~A},-{ }_{-} 3 \mathrm{~B},-{ }_{-3} \mathrm{C}$ respectively) were monitored via photography and recording of pertinent information (such as location of insect larvae, and portion of carcass above water) approximately every second day until all carcasses sank. Decay could not be observed in Treatment 1 aquaria (CR1A and 1B) for the duration of the experiment due to carcass burial, and in Treatment 2 aquaria (CR2A, - _2B, - - - 2C) after each carcass sank and was buried. As water clarity in Treatment 2 and 3 aquaria decreased as decay progressed, after each carcass had sunk, water was gently syphoned and bailed by hand from each aquarium in order to photograph the carcass positions. This water was then replaced by fresh tap water for the remainder of the experiment. Although a filtration system may have increased water clarity, it was not emplaced due to the experimental requirements for minimal disturbance, and because its effectiveness could not be guaranteed (a similar filtration methodology was employed by Brand et al. (2003) that resulted in clogging of filtration systems by organic debris, such as scales and soft tissue).

The experiment was halted on 26th February 2013; approximately 2 months after the last unburied carcass had progressed to the final stage of decay (the remains stage). At this point, buried carcasses were exhumed, photographed, and examined for articulation patterns. All water was drained from the remaining aquaria, and carcasses were photographed and examined for degree of articulation. The position of carcasses after they had first sunk and at the end of the experiment were compared to confirm no movement of visible skeletal elements had occurred due to water syphoning: minimal (less than $2 \mathrm{~mm}$ ) lateral movement of some manual and pedal digits in Treatment 3 carcasses was noted.

The degree of skeletal articulation for each carcass was recorded using a scoring system for fossil marine reptiles created by Beardmore et al. (2012b), who grouped skeletal elements into seven units: head (skull and mandible), neck (cervical vertebrae), trunk (prothoracic, thoracic, lumbar, and sacral vertebrae), tail (caudal vertebrae), ribs (thoracic ribs), left and right forelimbs (including pectoral girdles), 
and left and right hindlimbs (including hips and each pubis) (refer to schematic interpretation of CR1A in Fig. 8). In this system, the degree of skeletal articulation within each unit is scored from o to 4 , defined as follows:

Score o: no articulation in the head, neck, trunk, or tail units; o-_10\% articulation for ribs; or, no articulated joints in the forelimbs or hindlimbs;

Score 1: limited articulation in the head, neck, trunk, or tail units; $10-25 \%$ articulation for ribs; or, 1 of 4 articulated joints in the forelimbs or hindlimbs;

Score 2: moderate articulation in the head, neck, trunk, or tail units; 25 - $50 \%$ articulation for ribs; or, 2 of 4 articulated joints in the forelimbs or hindlimbs;

Score 3: near full articulation in the head, neck, trunk, or tail units; $50-75 \%$ articulation for ribs; or 3 of 4 articulated joints in the forelimbs or hindlimbs;

Score 4: full articulation of skeletal elements in the head, neck, trunk, or tail units; $75-100 \%$ articulation for ribs; or, 4 of 4 articulated joints in the forelimbs or hindlimbs.

See Beardmore et al. (2012b) for more detailed descriptions and example fossil specimen photographs for each definition. We chose this methodology as it not only allows for semi-quantitative analysis of qualitative data, but also allows for future comparison of articulation between extant vertebrate carcasses and fossil vertebrate specimens. We refer to this classification scheme as intra-unit articulation. Beardmore et al. (2012b) conducted statistical analyses using these measures of articulation along with a similar scoring system for completeness of fossils (ranging from ' 4 ' indicating all elements were present, to ' $\mathrm{O}$ ' indicating none were present): those analyses were not conducted for this study, as measures of completeness were artificially high and therefore not meaningful (loss of skeletal elements was prohibited by containment of each carcass within each aquarium, giving completeness scores of ' 4 ' for every carcass).

As the Beardmore et al. (2012b) classification scheme does not indicate the degree to which each skeletal unit articulates with another, we devised our own additional classification scheme to address this. We noted the presence of full articulation, partial articulation, or disarticulation between the head -and neck (base 
of cranium to the atlas-axis complex), neck -and trunk (cervical vertebra IX to (pro) thoracic vertebrae I), trunk - and tail (sacral vertebra II to caudal vertebra I), left and right forelimb - and trunk (scapula and coracoid to (pro) thoracic vertebrae I and II), and left and right hindlimb -and trunk (ilium to sacral vertebrae I and II). An interunit articulation category for ribs___trunk was not needed as the Beardmore et al. (2012b) 'ribs' intra-unit already accounted for the degree of rib articulation to the trunk. Full articulation was defined by the maintenance of in-vivo position, with no spaces or rotations between adjacent skeletal elements beyond what would be expected if the soft tissue (cartilaginous and ligamentous) parts of the joint were still in place. Partial articulation was categorized by the slight separation or rotation of adjacent skeletal elements, essentially the dislocation of a joint, where in-vivo position was not maintained but the external (dermal) anatomy would remain unaffected. Disarticulation was defined by the separation of adjacent skeletal elements, which could only occur if the soft tissue parts of the joint were no longer viable or the external (dermal) anatomy had been disrupted. We refer to this classification scheme as inter-unit articulation.

\section{Results}

\subsection{Ambient air and water temperatures}

The experiment ran for 160 days, from the 19th of September 2012 to the 26th of February 2013. Ambient temperature was recorded using a Maxim iButton ${ }^{\circledR}$ located on the perimeter of the study site, with the closest aquarium (CR1B/CR2A) approximately 1 metrem away. The recording began prior to the first day of the experiment (18th of September 2012), and due to technical issues with the internal clock of the Maxim iButton ${ }^{\circledR}$, ceased on the 24th of January 2013. Over this $\sim 4$ month period, the average daily minimum temperature was $19.9^{\circ} \mathrm{C}$ and the average daily maximum temperature was $31.9^{\circ} \mathrm{C}$. All minimum and maximum daily ambient air temperatures for this time period are shown inFig. 1. Water temperature was recorded using an YSI Model 85 Handheld water quality probe approximately every second day from the 19th of September 2012, to when the last Treatment 2 carcass was buried on the 28th of November 2012. These temperatures were recorded simultaneously to observations and photographic records taken. Water temperature recording ceased after water was drained from the Treatment 1 aquaria (on the 2nd of October 2012) and Treatment 2 aquaria (17th of November 2012 for $\mathrm{CR} 2 \mathrm{~B}$ and $\mathrm{CR} 2 \mathrm{C}$, and the 28th of November 2012 for $\mathrm{CR} 2 \mathrm{C}$ ). When all carcasses were either buried or had reached the remains stage, temperature recordings ceased. Although the temperatures recorded fluctuated due to changes in ambient 
temperature and time of day recorded, they remained relatively similar between and within treatments (see Fig. 2).

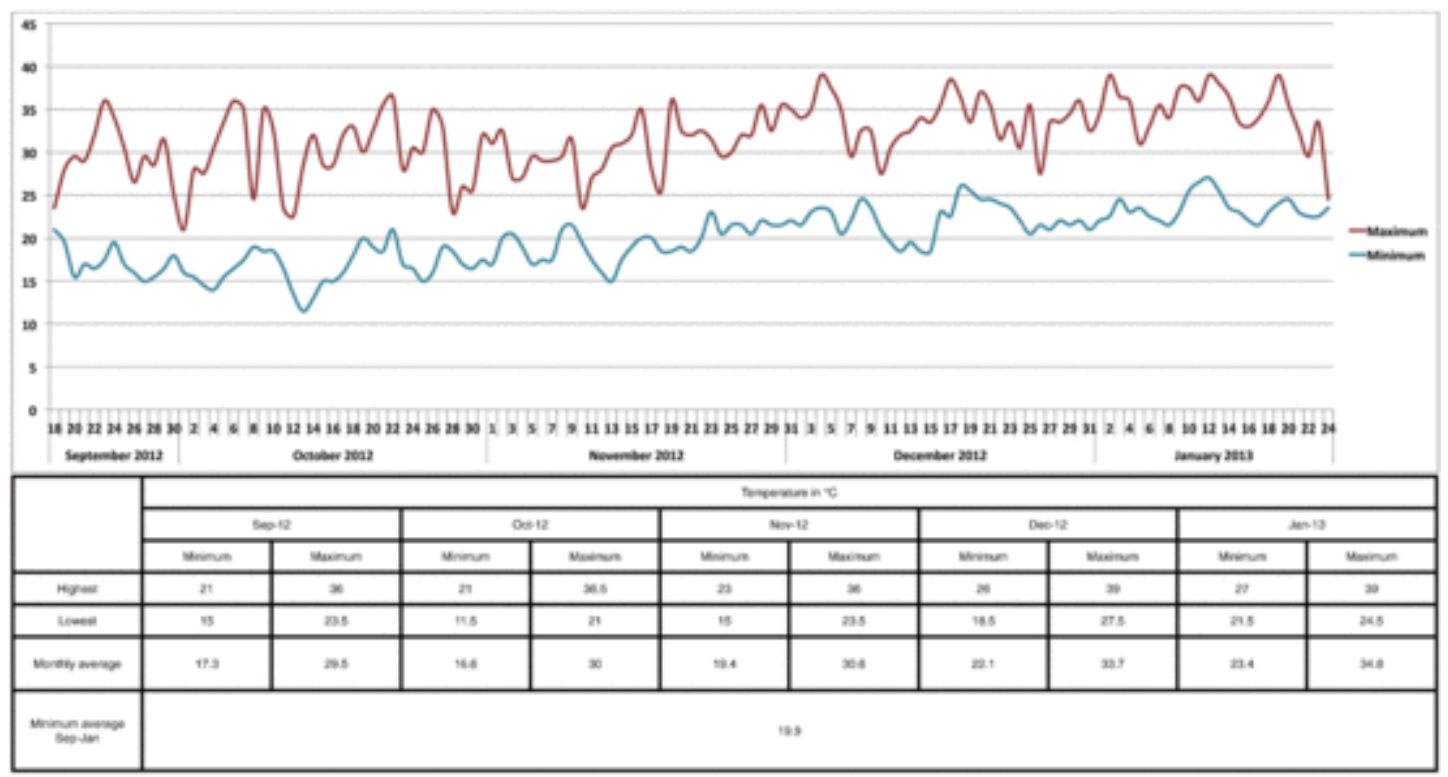

Fig. 1 Ambient air temperature recorded by a Maxim iButton ${ }^{\circledR}$ located 1 metremfrom perimeter from the study site. Measurements began one day prior to the start of the experiment on the 18th September, and due to an internal clock malfunction, ended on the 24th of January. The minimum and maximum temperatures are shown in the graph, with monthly minimums, maximums, and monthly and 5 monthly averages listed in the table below.

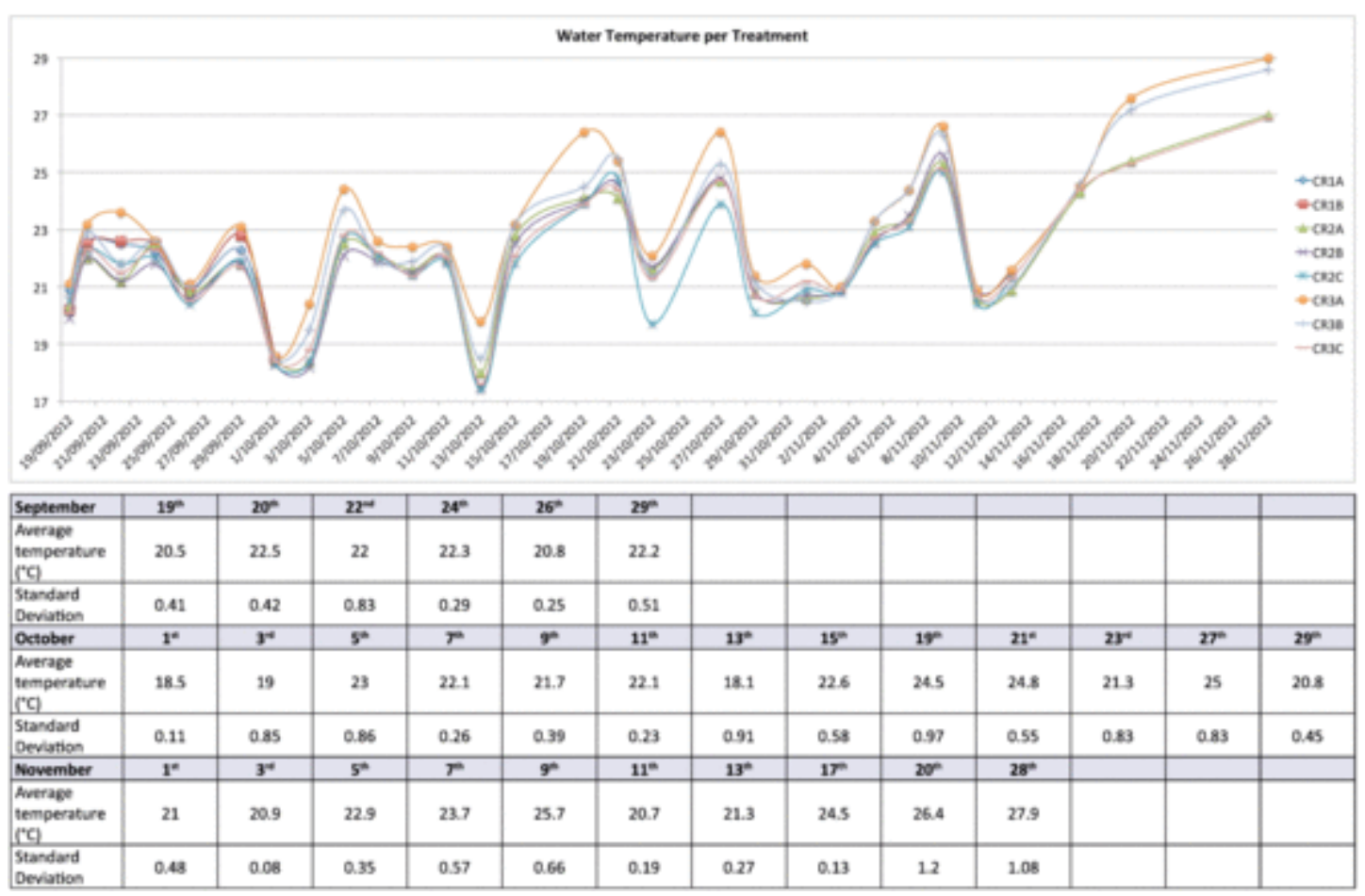

Fig. 2 Water temperature recorded for each treatment vessel. Water temperature recording ceased after water was drained from the Treatment 1 vessels (on the 2nd 
October 2012), and Treatment 2 vessels (17th November 2012 for CR2B and CR2C, and the 28th November 2012 for CR2C). As all carcasses were either buried or had reached the remains stage by the 28th November 2012, all recordings ceased on this day.

\subsection{Description \\ of C.Crocodylus porosusdecomposition}

The dates for each decay stage listed below indicate the average day on which each stage began, plus or minus the standard deviation, indicative of the variability between individuals. Table 3 shows the start date and length of time each carcass spent in each decay stage.

Table 3 Times taken for individual carcasses to progress through each decay stage, shown as the start date of each decay stage, and the total time spent in each decay stage. 'NA'indicates where observations were not possible due to carcass burial. The remains stage does not end until skeletal material is destroyed or fossilized, therefore the total length of time for this stage was not recorded. The mean, standard deviation, and standard error of the start of each decay stage and the length of time to progress through each stage is also shown.

\begin{tabular}{|c|c|c|c|c|c|c|c|c|c|}
\hline & \multirow{2}{*}{$\begin{array}{l}\text { Decay } \\
\text { stage }\end{array}$} & \multicolumn{2}{|c|}{ Treatment 1} & \multicolumn{3}{|c|}{ Treatment 2} & \multicolumn{3}{|c|}{ Treatment 3} \\
\hline & & CR1A & CR1B & CR2A & CR2B & CR2C & CR3A & CR3B & CR3C \\
\hline \multirow[t]{5}{*}{ Starting day } & Fresh & Day 1 & Day 1 & Day 1 & Day 1 & Day 1 & Day 1 & Day 1 & Day 1 \\
\hline & Bloated & NA & NA & Day 3 & Day 4 & Day 5 & Day 4 & Day 4 & Day 3 \\
\hline & $\begin{array}{l}\text { Active } \\
\text { decay }\end{array}$ & NA & NA & $\begin{array}{l}\text { Day } \\
17\end{array}$ & $\begin{array}{l}\text { Day } \\
11\end{array}$ & $\begin{array}{l}\text { Day } \\
13\end{array}$ & $\begin{array}{l}\text { Day } \\
11\end{array}$ & $\begin{array}{l}\text { Day } \\
11\end{array}$ & $\begin{array}{l}\text { Day } \\
21\end{array}$ \\
\hline & $\begin{array}{l}\text { Advanced } \\
\text { decay }\end{array}$ & NA & NA & $\begin{array}{l}\text { Day } \\
31\end{array}$ & $\begin{array}{l}\text { Day } \\
25\end{array}$ & $\begin{array}{l}\text { Day } \\
19\end{array}$ & $\begin{array}{l}\text { Day } \\
21\end{array}$ & $\begin{array}{l}\text { Day } \\
21\end{array}$ & $\begin{array}{l}\text { Day } \\
27\end{array}$ \\
\hline & Remains & NA & NA & NA & NA & NA & $\begin{array}{l}\text { Day } \\
71\end{array}$ & $\begin{array}{l}\text { Day } \\
41\end{array}$ & $\begin{array}{l}\text { Day } \\
54\end{array}$ \\
\hline \multirow{5}{*}{$\begin{array}{l}\text { Length of } \\
\text { stage (in } \\
\text { days) }\end{array}$} & Fresh & NA & NA & 3 & 5 & 5 & 3 & 3 & 2 \\
\hline & Bloated & NA & NA & 14 & 7 & 8 & 7 & 7 & 18 \\
\hline & $\begin{array}{l}\text { Active } \\
\text { decay }\end{array}$ & NA & NA & 14 & 14 & 6 & 10 & 10 & 6 \\
\hline & $\begin{array}{l}\text { Advanced } \\
\text { decay }\end{array}$ & NA & NA & NA & NA & NA & 50 & 20 & 27 \\
\hline & Remains & NA & NA & NA & NA & NA & NA & NA & NA \\
\hline
\end{tabular}




\begin{tabular}{|l|l|l|l|l|}
\hline & Decay stage & Mean & Standard deviation & Standard error \\
\hline \multirow{2}{*}{ Starting day } & Fresh & Day 1 & 0.00 & 0.41 \\
\hline & Bloated & Day 3.8 & 0.75 & 1.56 \\
\hline & Active decay & Day 14 & 4.15 & 5.72 \\
\hline & Advanced decay & Day 24 & 4.52 & 9.80 \\
\hline \multirow{2}{*}{ Length of stage (in days) } & Remains & Day 55.3 & 15.04 & 22.59 \\
\hline & Fresh & 3.50 & 1.22 & 0.50 \\
\hline & Bloated & 10.2 & 4.71 & 1.92 \\
\hline & Active decay & 10.00 & 3.58 & 1.46 \\
\hline & Advanced decay & 32.33 & 15.70 & 9.06 \\
\hline & Remains & NA & NA & NA \\
\hline
\end{tabular}

\subsubsection{Treatment 1: rapid burial scenario}

\subsubsection{Fresh stage: $\operatorname{day} 1 \pm 0$}

The carcasses (CR1A and CR1B) were placed in the aquaria dorsal side up, and immediately sunk to the bottom of the aquaria, without any assistance, in this same orientation prior to burial.

\subsubsection{Bloated stage: exact date unknown}

CR1A remained buried for the duration of this stage; therefore no observations could be made, although presumably it underwent bloat underground. However, the same process of internal gas production and resulting buoyancy within the body cavity of $\mathrm{CR} 1 \mathrm{~B}$ overcame the downward pressure of the sand it was buried under, which resulted in it rising and floating to the surface ventral side up on day 12. CR1B was re-buried on the day 13 of the experiment, with excess water drained from both Treatment 1 aquaria for two reasons: (1) so that both buried carcasses underwent the same experimental variables, and (2) to eliminate the possibility of CR1A also floating.

\subsubsection{Active decay stage/advanced decay stage: exact dates unknown}

Carcasses remained buried for the duration of these stages; therefore observations could not be made.

\subsubsection{Remains stage: exact date unknown}

The buried carcasses were unearthed on day 161 (26th of February 2013). Both carcasses had already reached the remains stage, with extensive soft tissue 
decay leaving behind only the mummified dermis and cuticle, and some adipocere alongside the caudal vertebrae from the saponification of fatty tissue. Skeletal elements, including osteoderms, were all in their in-vivo positions. The exact position of skeletal elements is described in Section 3.4.1.

\subsubsection{Treatment 2: aquatic decay scenario (buried after sinking), and Treatment 3: aquatic decay scenario (not buried)}

\subsubsection{Fresh stage: day $1 \pm 0$}

The carcasses were placed in the aquaria facing dorsal side up, and immediately sunk to the bottom of the aquaria, without any assistance, in this same orientation. Slight variations in limb orientations occurred for each individual; however, in most instances the limbs were protracted and abducted, and flexed at the elbow/knee, with the medial surface facing up.

\subsubsection{Bloated stage: day $3.8 \pm 0.75$}

After an average of 3 days the carcasses bloated, and 24-48 hoursh later began to rise through the water column rotating on their long axis to float ventral side up (excluding $\mathrm{CR} 2 \mathrm{C}$, which rotated on its long axis to float left lateral side up). While floating, the head and neck of each carcass was initially at the water then began to flex dorsally such that they remained below the water line, whereas the medial (rarely cranial) surface of each limb and the ventral surface of the trunk was exposed above the water line-_excluding CR2C, which only had the left-most ventral and lateral surfaces of the head and trunk and the lateral surface of each left limb exposed, with the head eventually flexing left laterally. Initially, the terminal half of the tail remained below the water line for all carcasses, progressively flexing more dorsally as decay progressed the entire length of the tail. Between day 5 and day 7 , the cloaca of each carcass was visited by flying insects. The end of the bloat stage in this experiment did not necessarily correlate with each carcass sinking, but rather the onset of scavenging of portions of the body that were subaerially exposed, which in turn lead to the onset of active decay stage. Gas bubbles in the form of white foam were observed around the mouth and cloaca, and near the surgical wound in the right hindlimb (see Fig. 3) from the escape of endogenously produced gases, also marking the end of the bloat stage. 


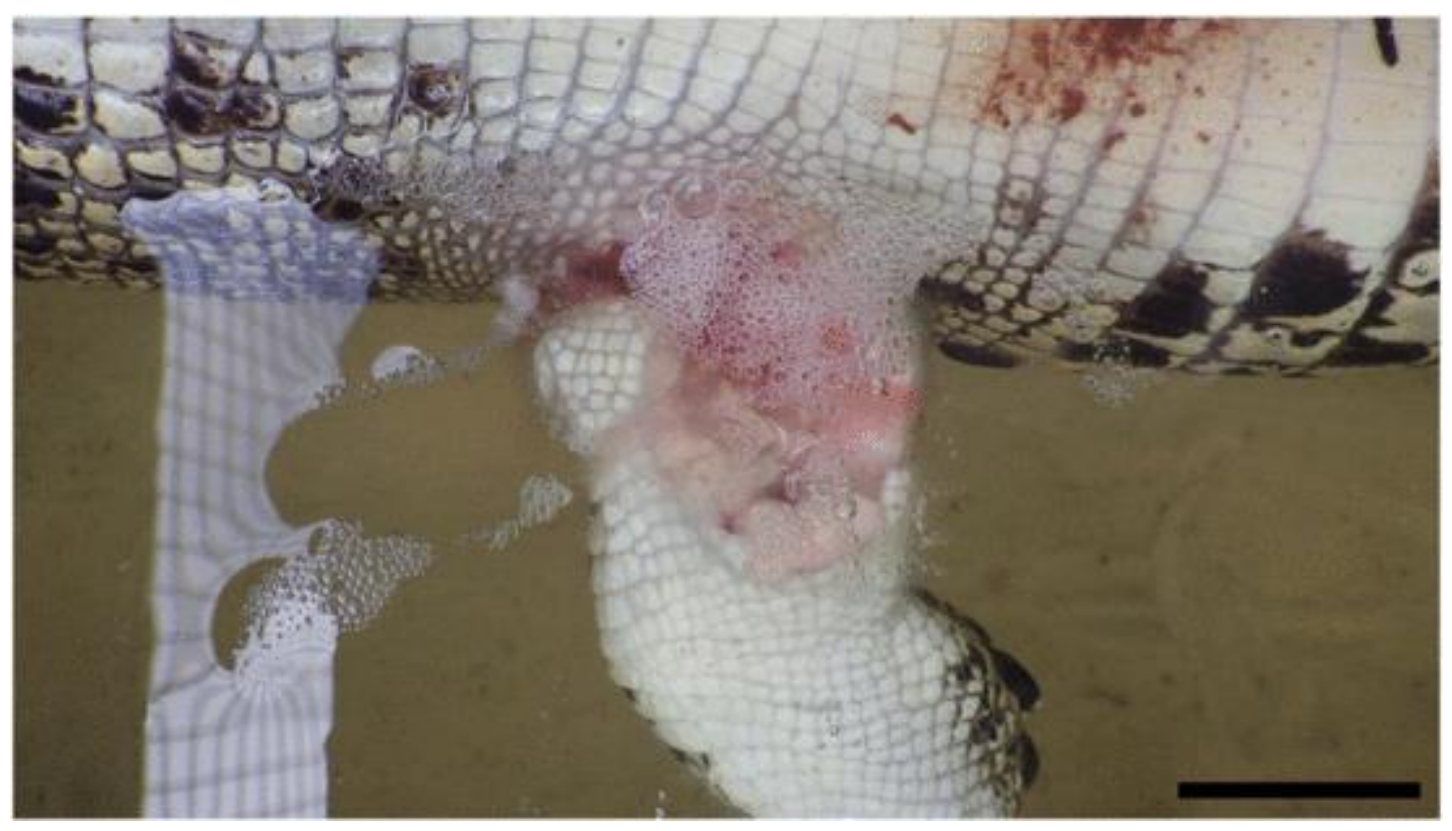

Fig. 3 Photograph of ventral surface of right hindlimb and trunk of CR3B on day 6 (during bloated stage). Gas bubbles in the form of white foam can be seen in the water above the right hindlimb incision point. Scale bar represents $2 \mathrm{~cm}$.

\subsubsection{Active decay stage: day $14 \pm 4.15$}

Visible larval insect scavenging of exposed soft tissue began on days 11-13, excluding for $\mathrm{CR} 2 \mathrm{~A}$ and $\mathrm{CR}_{3} \mathrm{C}$ where larval scavenging only began after day 17 and day 21, respectively. Larvae were smooth and pale, ranged in size between 8and $12 \mathrm{~mm}$, and using the identification key outlined in O'-Flynn and Moorhouse (1980), were identified asCalliphora and Lucilia spp. Most larval activity began in and focused around the cloaca. One exception was $\mathrm{CR} 2 \mathrm{C}$, which continued floating left lateral side up with the cloaca below the water line. Even though other orifices of $\mathrm{CR} 2 \mathrm{C}$ were situated above the water line (left oral region, left orbit, and left external auditory aperture), larvae were concentrated on the cuticle of the left lateral surface of the trunk, distributed cranially to the shoulder and caudally to the base of the tail, eventually breaking through the subepidermis and dermis. In all other carcasses, larval activity progressed from the cloaca along the ventral surface, then cranially to the throat and terminally to the first quarter of the tail, along the subepidermis beneath the cuticle. The consumption of the subepidermis disrupted and moved the cuticle layer off the ventral surface. The larvae eventually broke through the subepidermis and dermis exposing muscle and internal organs.

\subsubsection{Advanced decay stage: day $24 \pm 4 \cdot 52$}

As decay continued, skeletal elements (primarily thoracic ribs, the pubic bones and ischia) were exposed and became disarticulated at their respective joints. Exposure and disarticulation resulted not only from the direct removal 
(consumption) of muscle, tendons and surrounding fascia by larvae, but also from the 'tugging' feeding action employed by many of the larvae, pulling soft tissue back and forth at least 0.5 to $1 \mathrm{~cm}$ (seeFig. 4). Between days 19 and 31, carcasses started to submerge and then slowly sink. Insect larvae evacuated the soft tissue as it sunk. Due to the turbidity of the water, continued sinking and eventual contact with the substrate could not be viewed first hand. As carcasses retained skeletal articulation while floating (excluding disarticulation of some thoracic ribs, the pubic bones and ischia as described above), and disarticulation was observed after the carcass had sunk and water was gently drained from the aquaria (so the degree of articulation could be documented), we deduce that the majority of disarticulation occurred when the carcasses contacted the substrate. Due to the lack of disturbance in the aquaria and the position of the carcasses during decay and while sinking (with the head and whole of tail submerged, creating an inverted U-shape profile), the mostly likely source of this disarticulation was the pressure placed on skeletal elements and decayed joints at the sediment__water interface as the body succumbed to gravitational forces, 'buckled' and pressed on other body parts, causing bones to move out of life position. Treatment 2 carcasses were buried during this stage, with a top layer of water added then drained 13 days after burial to replicate the Treatment 1 variables. 


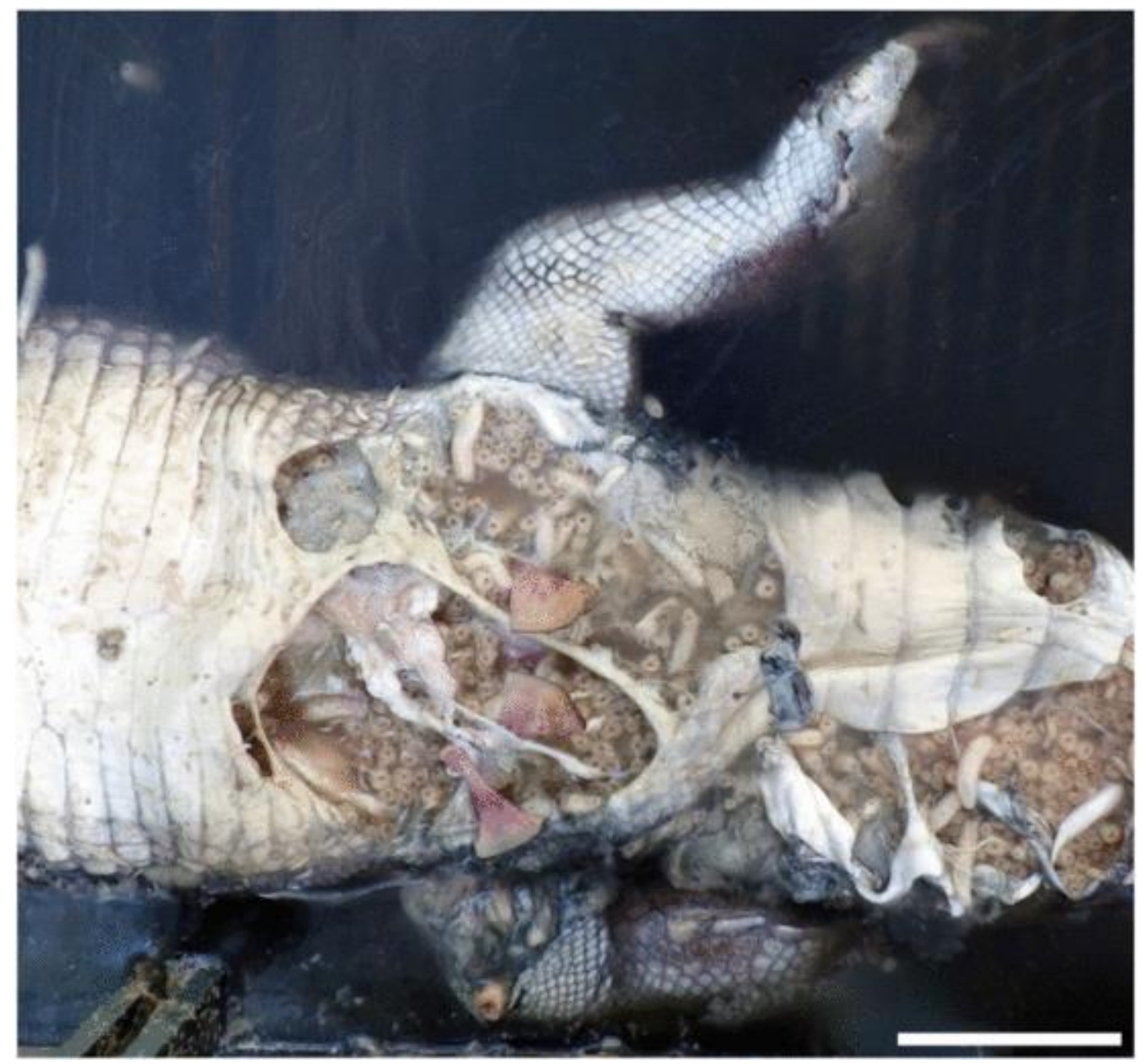

Fig. 4 Photograph of the belly and ventral surface of the tail base of CR3A on day 21 (during advanced decay). Cranial is to the left, with the ventral surface of the left and right hindlimbs visible at the water's's surface. Insect larvae are feeding on the flesh around the cloaca, exposing the left and right ischium-ischia (image centre) and the right pubis, which has become detached and rotated to now sits lateral to the left ischium. Scale bar represents $5 \mathrm{~cm}$.

\subsubsection{Remains stage: day $55.3 \pm 15.04$}

Only the unburied carcasses (Treatment 3 ) could be examined for visible signs of the end of the advanced decay stage and the remains stage. These carcasses continued to decay subaqueously via necrolysis and from mosquito larvae feeding on soft tissue, exposing more than fifty percent $50 \%$ of the skeleton. The mosquito larvae averaged $2 \mathrm{~mm}$ in length, and were not strong enough to move or disarticulate any bones. The majority of soft tissue was decayed, excluding some dermis, cuticle, and adipocere resulting from saponification of fatty tissues, exposing the underlying disarticulated skeletal elements. Soft tissue decay continued until the end of the experiment on day 161. 
Figs. 5 and 6 show the general pattern of the five stages of decay observed in Treatment 2 and 3 crocodiles. The exact positions of skeletal elements are described in Section 3.4.

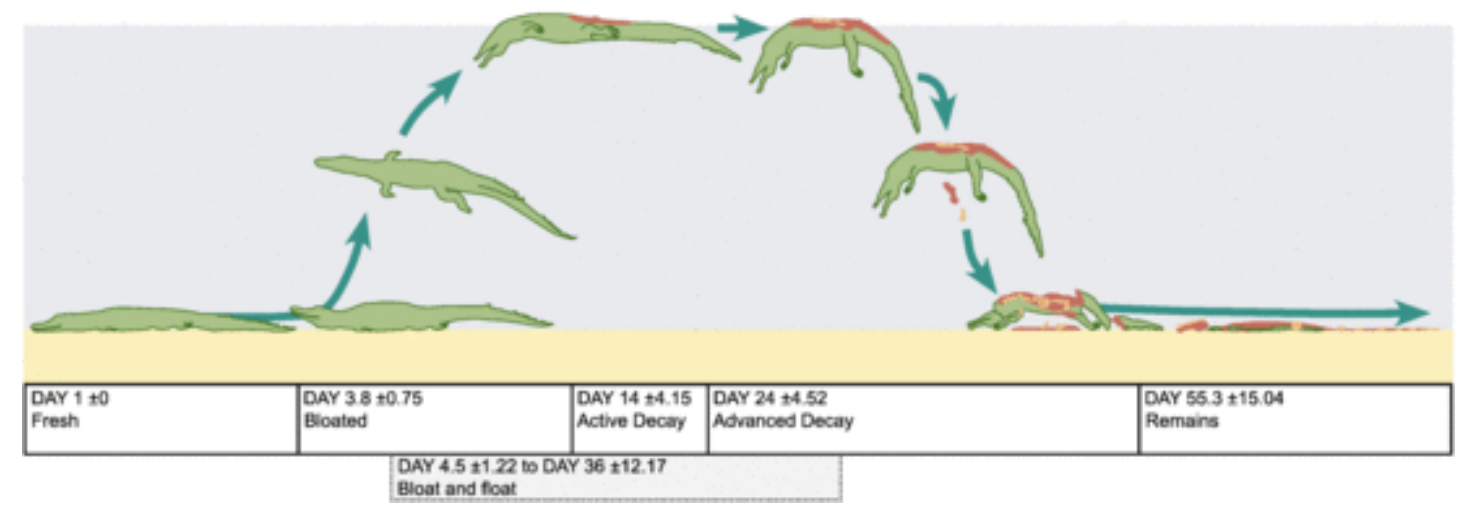

Fig. 5 Stages of decay shown as outlines in lateral view. Day number, equivalent to number of day'-_s post-mortem, indicates average starting day of each stage. 'Bloat and float' commenced during the bloated stage and continued through to the advanced decay stage.

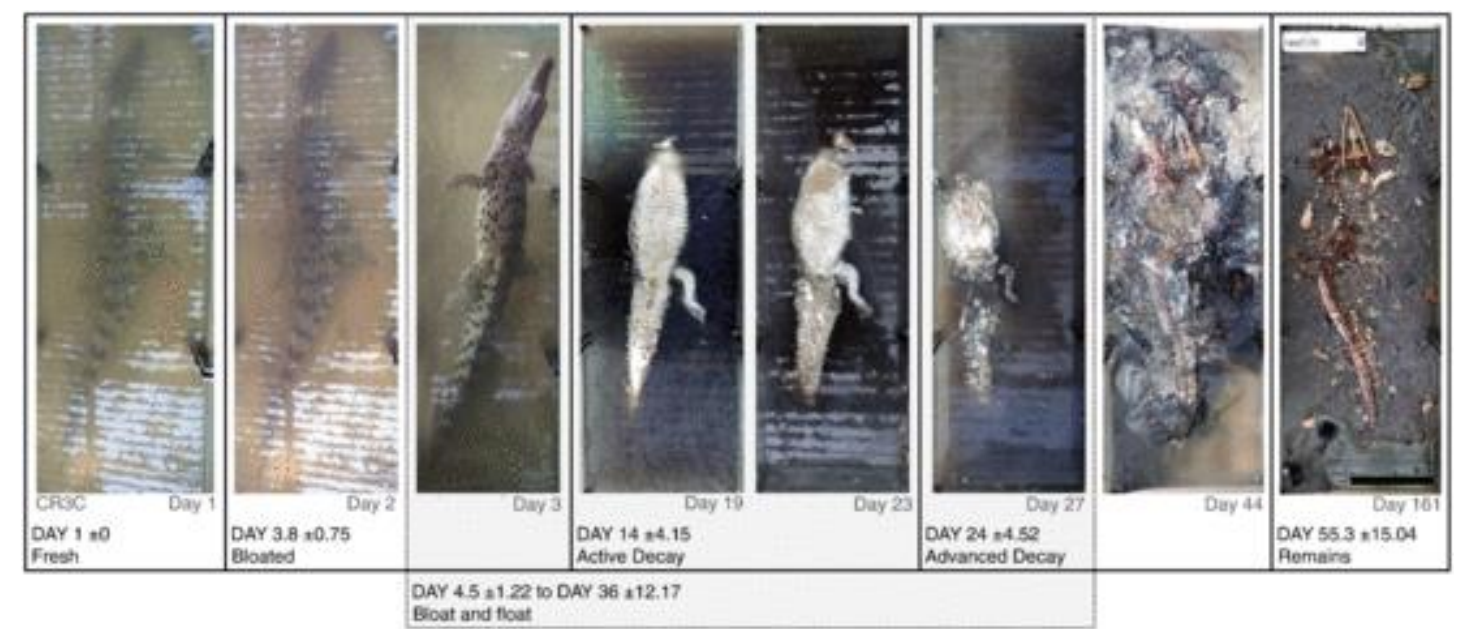

Fig. 6 Photographs of typical decay stages experienced by juvenile C.Crocodylusporosus in fresh water, taken from directly above the carcass. Average starting day of each stage indicated by day number \pm standard deviation, equivalent to number of days post-mortem. 'Bloat and float' commenced during the bloated stage and continued through to the advanced decay stage. Photographs are of $\mathrm{CR}_{3} \mathrm{C}$ carcass, day of photograph indicated in grey. Scale bar represents $10 \mathrm{~cm}$.

\subsection{Patterns of decay and disarticulation in floating carcasses}

All the crocodile carcasses in Treatments 2 and 3 floated after reaching the bloated stage. One crocodile carcass in Treatment 1, CR1B, also floated (see previous description in 'Treatment 1__bloat'). On average, carcasses spent 32 days 
( \pm standard deviation of 12.79 days) floating: the average pattern and timing is outlined below.

Three days post-mortem, the carcass showed visible signs of bloat (abdominal swelling).

After the carcass began to bloat, it took 24-48 hoursh for it to float and rise $20 \mathrm{~cm}$ to the surface of the water. This marked the beginning of 'bloat and float'.

The carcass floated for approximately 19 days, initially with the majority having their ventral surfaces subaerially exposed (from the tip of the mandibular rostrum to the terminus of the tail, the medial surfaces of the limbs, and palmar/plantar surfaces of the manus/pedes respectively). Sinking of the tail progressed from the tip cranially, with the terminal-most portion being the first to fall below the surface of the water. Similarly, sinking of the head progressed from the tip of the rostrum caudally. White foam was observed around the mouth, cloaca, and pre-experiment right hindlimb surgical wound (see Fig. 3). All carcasses stayed articulated during this initial float period, and during both the bloat and the active decay stages.

Over the next 12 days, the neck and the entire length of the tail submerged, with the head, limbs, and terminal half of the tail beginning to sink. The pubic bones, gastralia, and some thoracic ribs were exposed and disarticulated, coinciding with the start of advanced decay. As decay progressed, the trunk and tail base remained at the water-'s surface while the head, neck, forelimbs, hind limbs, and the remainder of the tail continued to become more submerged, without disarticulating. This resulted in an inverted U shape profile for all carcasses (see Fig. 7).

The end of 'bloat and float' occurred when the carcass sunk over the next 11day period and settled on the bottom of the aquarium. It is important to note that the end of the bloated stage did not coincide with the cessation of floating: carcasses continued to float while progressing through the active decay stage and part of advanced decay stage. 


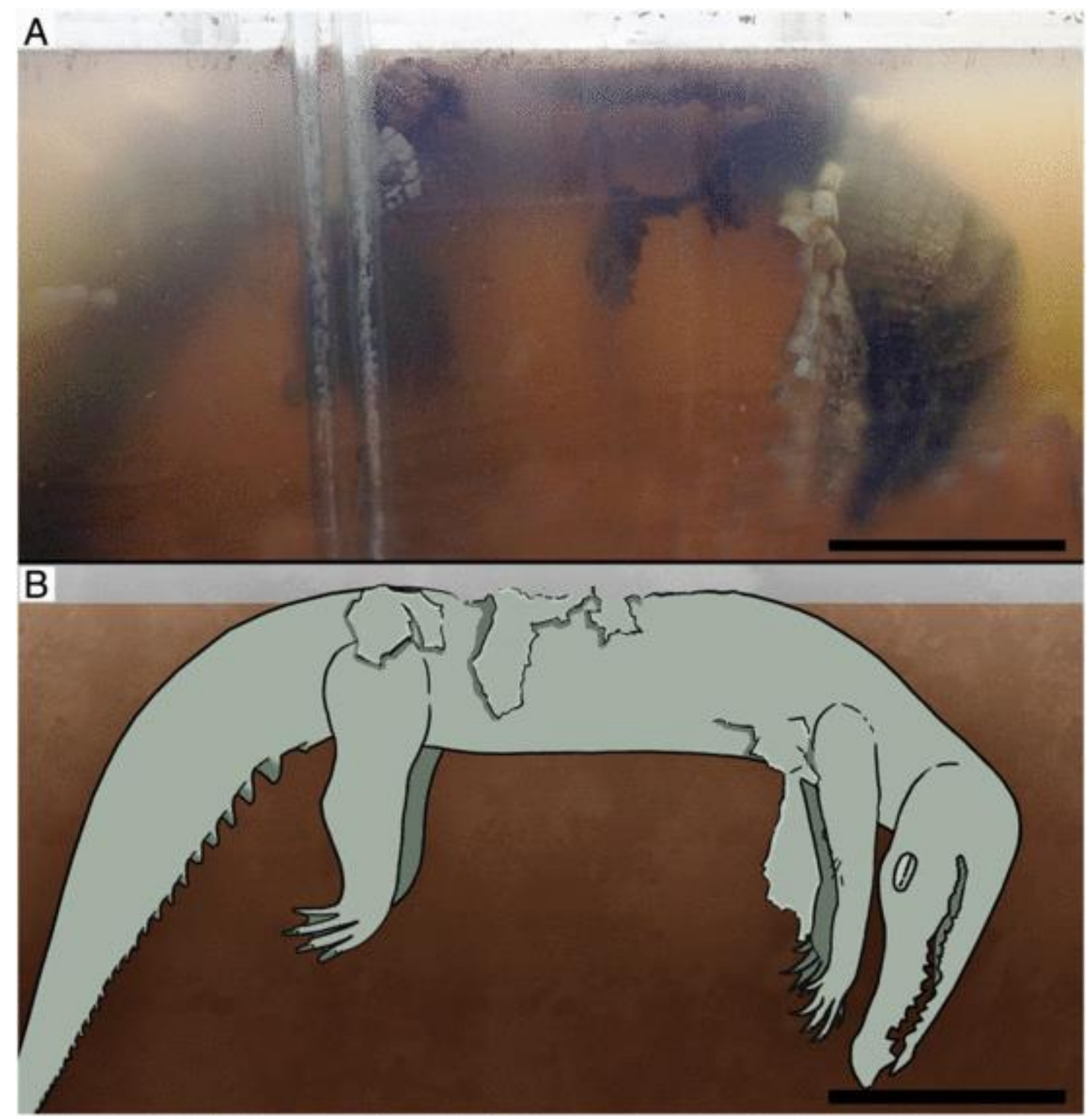

Fig. 7 Photograph and illustration of the inverted U-shaped profile typical of floating carcasses during the advanced decay stage. (A) Photograph of CR2A (Day 33) in left lateral aspect, floating ventral surface up, exhibiting the inverted U-shaped profile common in Treatment 2 and Treatment 3 carcasses during the advanced decay stage. A portion of skin from the ventral surface of the trunk and neck has partially detached and is hanging across the left side of the body, obscuring the left forelimb, neck, and part of the head. Scale bar represents $10 \mathrm{~cm}$. (B) Stylized drawing of CR2A from the photograph in panel A. Some of the partially detached skin was not drawn so as to show the position of the left forelimb, neck, and head. Scale bar represents $10 \mathrm{~cm}$.

\subsection{End of experiment articulation}

The results are described below for each treatment, and intra- and inter-unit articulation stage scores are summarized in Tables 4 and 5, respectively. As per the Beardmore et al. (2012b) generalized vertebrate bauplan, minor skeletal 
elements (e.g. gastralia, hyoids, teeth) were not included in the analysis of skeletal articulation.

Table 4 Intra-unit articulation scores using Beardmore et al. (2012b) classification scheme. Refer to Fig. 1 for skeletal units used. Treatment 1 carcasses showed highest intra-articulation scores due to burial during the fresh stage. Treatment 2 and 3 carcasses showed lower intra-unit articulation scores due to soft tissue decay in water and gravitational forces upon sinking forcing skeletal elements out of in-vivo positions. Treatment 2 carcasses overall scored higher than Treatment 3 carcasses, as they were buried during the advanced decay stage with some soft tissue still attached.

\begin{tabular}{|c|c|c|c|c|c|c|c|c|}
\hline \multirow[t]{2}{*}{ Intra-unit articulation } & \multicolumn{2}{|c|}{ Treatment 1} & \multicolumn{3}{|c|}{ Treatment 2} & \multicolumn{3}{|c|}{ Treatment 3} \\
\hline & CR1A & CR1B & CR2A & CR2B & CR2C & CR3A & CR3B & CR3C \\
\hline Head & 4 & 4 & 4 & 4 & 4 & 0 & 4 & 4 \\
\hline Neck & 4 & 3 & 4 & 4 & 4 & 2 & 2 & 0 \\
\hline Trunk & 4 & 4 & 3 & 2 & 4 & 2 & 2 & 2 \\
\hline Ribs $^{\mathrm{a}}$ & 4 & 3 & 0 & 0 & 0 & 0 & 0 & 0 \\
\hline Tail & 4 & 4 & 4 & 2 & 4 & 0 & 1 & 2 \\
\hline $\mathrm{L}$ forelimb & 4 & 4 & 0 & 1 & 4 & 0 & 0 & 2 \\
\hline $\mathrm{R}$ forelimb & 4 & 4 & 0 & 1 & 4 & 0 & 0 & 2 \\
\hline L hindlimb & 4 & 4 & 3 & 1 & 3 & 1 & 0 & 1 \\
\hline $\mathrm{R}$ hindlimb & 4 & 4 & 3 & 1 & 3 & 1 & 0 & 1 \\
\hline
\end{tabular}

aThe 'ribs' skeletal unit defines articulation between ribs and the thoracic vertebrae, and therefore is technically a measure of inter-unit articulation, not intra-unit articulation. However, as the 'ribs' unit was defined by Beardmore et al. (2012b), we have opted to keep it in the intra-unit articulation category.

Table 5 Inter-unit articulation scores between skeletal units, where ' $F$ ' indicates full inter-unit articulation___ in contact, no breaks (rotations or spaces), 'P' indicates partial inter-unit articulation __ skeletal elements in contact or near-to, but rotated out of life position, and ' $\mathrm{D}$ ' indicates inter-unit disarticulation_—_ skeletal elements are not in contact and not in-vivo. Treatment 1 carcasses showed highest inter-articulation scores due to burial during the fresh stage. Treatment 2 and 3 carcasses showed lower inter-unit articulation scores due to soft tissue decay in water and gravitational forces upon sinking forcing skeletal elements out of in-vivo positions.

Treatment 2 carcasses overall scored higher than Treatment 3 carcasses, as they were buried during the advanced decay stage with some soft tissue still attached.
Inter-unit articulation
Treatment 1
Treatment 2
Treatment 3 


\begin{tabular}{|l|l|l|l|l|l|l|l|l|}
\hline & CR1A & CR1B & CR2A & CR2B & CR2C & CR3A & CR3B & CR3C \\
\hline Head__neck & F & P & D & P & D & D & D & D \\
\hline Neck__trunk & F & F & F & F & F & P & P & P \\
\hline Trunk_ttail & F & F & F & F & F & P & P & F \\
\hline L forelimb_trunk & F & F & D & D & D & D & D & D \\
\hline R forelimb_trunk & F & F & D & D & D & D & D & D \\
\hline L hindlimb_trunk & F & F & D & D & D & P & D & D \\
\hline R -hindlimb_trunk & F & F & D & D & P & D & D & D \\
\hline
\end{tabular}

\subsubsection{Treatment 1-_ - buried one day post mortem}

As seen in Fig. 8, skeletal elements of Treatment 1 crocodile carcasses maintained their initial post-mortem positions and showed high intra-unit articulation scores with full inter-unit articulation, as shown in Tables 4 and 5 . No overlaps, rotations, or greater than expected spaces between skeletal elements were observed, excluding the thoracic rib $\mathrm{X}$ and the atlas of CR1B, most likely dislodged during 'bloat and float' on days 12 and 13. The fore- and hindlimbs of both carcasses remained in their post-mortem pre-burial positions. The forelimbs of CR1A were protracted with minor flexion at the elbow and flexion of the left manus and extension of the right manus, whereas in $\mathrm{CR} 1 \mathrm{~B}$ the right forearm is protracted and flexed at the elbow and neutral at the carpus, and the left is partially retracted and flexed at the elbow and partially adducted at the shoulder. The hindlimbs of both CR1A and CR1B are protracted and flexed at the knee and the tarsus, excluding CR1B, which shows extension of the right pes. The left manus of CR1A is preserved lateral surface up, whereas the left manus of CR1B is preserved medial surface up, with both right manus preserved dorsal surface up. For the left manus of each carcass, the plane defined by the palmar surface is parallel to the sagittal plane, whereas for the right manus of each carcass, the same plane is parallel to the horizontal. The pedes of both carcasses were preserved medial surface up, such that the plane defined by the plantar surface is parallel to the sagittal plane, except for the right pes of CR1A, which lies dorsal surface up with the plantar surface parallel to the horizontal plane. This resulted in the vertical preservation of metacarpals, metatarsals, and digits. 

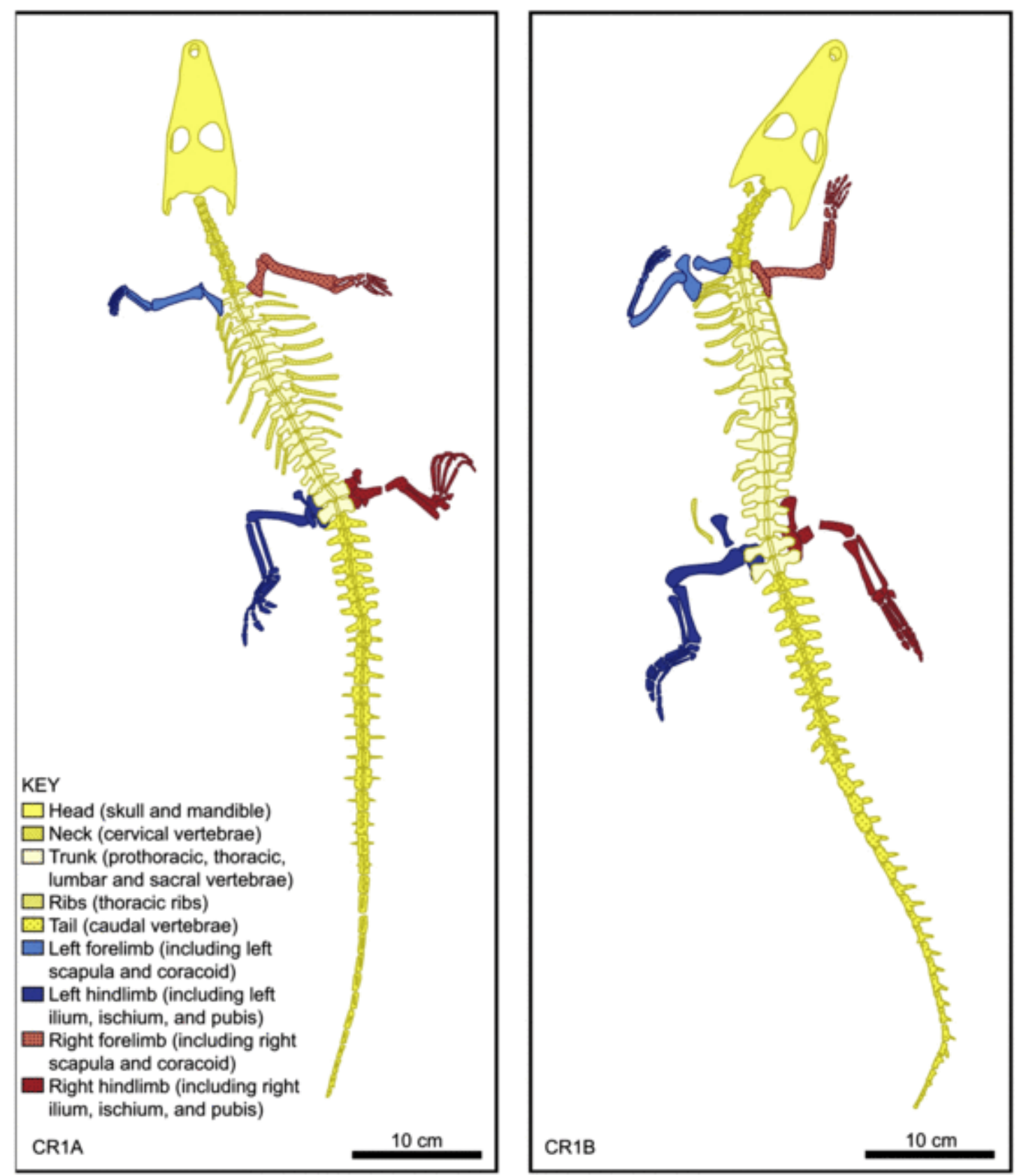

Fig. 8 Schematic outline of skeletal elements for Treatment 1 carcasses. The skeletal units used are modified from Beardmore et al. (2012b), and are defined in the key as follows: head (skull and mandible), neck (cervical vertebrae), trunk (prothoracic, thoracic, lumbar, and sacral vertebrae), tail (caudal vertebrae), ribs (thoracic ribs), left and right forelimbs (including pectoral girdles), and left and right hindlimbs (including hips and each pubis). The combination of the pectoral girdle unit with forelimb unit, and hip unit with the hindlimb unit, are equivalent to the Beardmore et al. (2012b) forelimb and hindlimb units respectively. All elements were drawn looking down on the carcass as it lay in the sediment, such that some elements appear distorted due to parallax. The antibrachial elements of CR1A have their distal ends angled into the sediment so appear shortened. The axial skeleton is preserved 
dorsal side up, excluding the terminal half of the tail on CR1B, the vertebrae of which are preserved left lateral surface up. The manus and pes have their palmar and plantar surfaces parallel to the sagittal plane, thereby allowing for vertical preservation of elements through the burial medium. The right femur on these and all other specimens was sectioned prior to the experiment, but both the distal and proximal portions of all femora remained roughly in their in vivo position during decay due to the presence of surrounding soft tissue and burial medium. These skeletal configurations are representative of carcasses buried during the fresh stage. Scale bar represents $10 \mathrm{~cm}$.

\subsubsection{Treatment 2-_- subaerial decay prior to burial upon sinking}

In contrast to Treatment 1 , skeletal elements of Treatments 2 carcasses (Fig. 9) ranged from fully articulated to disarticulated. Some skeletal elements were preserved vertically through the burial medium; in CR2A, thoracic vertebra X, lumbar vertebrae I to $\mathrm{V}$, sacral vertebrae I and II, and caudal vertebrae I-V lay approximately $0.2 \mathrm{~cm}$ dorsal to articulated cervical vertebrae, prothoracic vertebrae I-II, and thoracic vertebrae III_ _IX. The remaining skeletal elements of CR2A, and all skeletal elements in CR2B and CR2C, were distributed laterally, not vertically. The highest intra-unit articulation scores were for the head, with the skull and mandible for each carcass remaining articulated and laying ventral side up, and the neck, with the cervical vertebrae flexed dorsally in each carcass (all carcasses scoring ' 4 ' for both units). However, inter-unit articulation between the head and the neck varied from partially articulated for CR2B, to disarticulated for CR2A and CR2C. Full interunit articulation was observed between the neck and the trunk, and the trunk and the tail. The majority of thoracic ribs in all three carcasses became disarticulated from the trunk (scoring ' $\mathrm{O}$ ' for intra-unit articulation). Although full inter-unit articulation was maintained between the trunk and tail for all carcasses, the degree of intra-unit articulation within the trunk, tail, left and right forelimbs and hindlimbs, and interunit articulation between the neck - $\underline{\text { and }}$ trunk, and hindlimb - and trunk, were not consistent between Treatment 2 individuals (see Tables 4 and 5). Carcasses CR2A and CR2B had portions of the vertebral column from the trunk and tail separated into articulated sections; where these breaks in occurred within the vertebral column was not consistent within or between carcasses. CR2C, the only carcass to float left lateral side up instead of ventral surface up, was the only Treatment 2 carcass to maintain articulation along the entire length of the vertebral column. Those limbs that retained full, near, moderate, or limited intra-unit articulation were preserved in 
a variety of positions with skin still intact on some manus and pedes. For example, the left and right forelimbs of $\mathrm{CR}_{2} \mathrm{C}$ were flexed at the elbow and extended at the carpus, the left and right hindlimbs of CR2A were flexed at the knee and flexed at the tarsus and metatarsus, and the left and right hindlimb of CR2C and left hindlimb of CR2B were extended at the knee and extended at the tarsus. CR2A showed no intraunit articulation of left and right forelimb elements (scoring ' $O$ ' for each), whereas its hindlimbs retained near-full articulation (with an intra-unit articulation score of ' 3 ' for each). CR2B suffered the same degree of limited articulation for all limbs (scoring ' 1 ' for intra-unit articulation of both forelimbs and hindlimbs). Only CR2C maintained full articulation of the left and right forelimb (scoring ' 4 ' for intra-unit articulation for each limb), with near-full articulation of the left and right hindlimb (with an intra-unit articulation score of ' 3 ' for each). In all three carcasses, forelimbs and hindlimbs (including pectoral and pelvic girdles respectively) disarticulated from the trunk, excluding the partially articulated right hindlimb of CR2C. Although the degree and pattern varied between individuals, intra- and inter-unit limb articulation on average was mirrored between the left and right sides of each individual; when the left forelimb or hindlimb showed higher degrees of intra- and inter-unit articulation, so did the right forelimb or hindlimb, even with the right dorsal femoral muscles and the femur of each carcass being severed prior to the start of the experiment. 

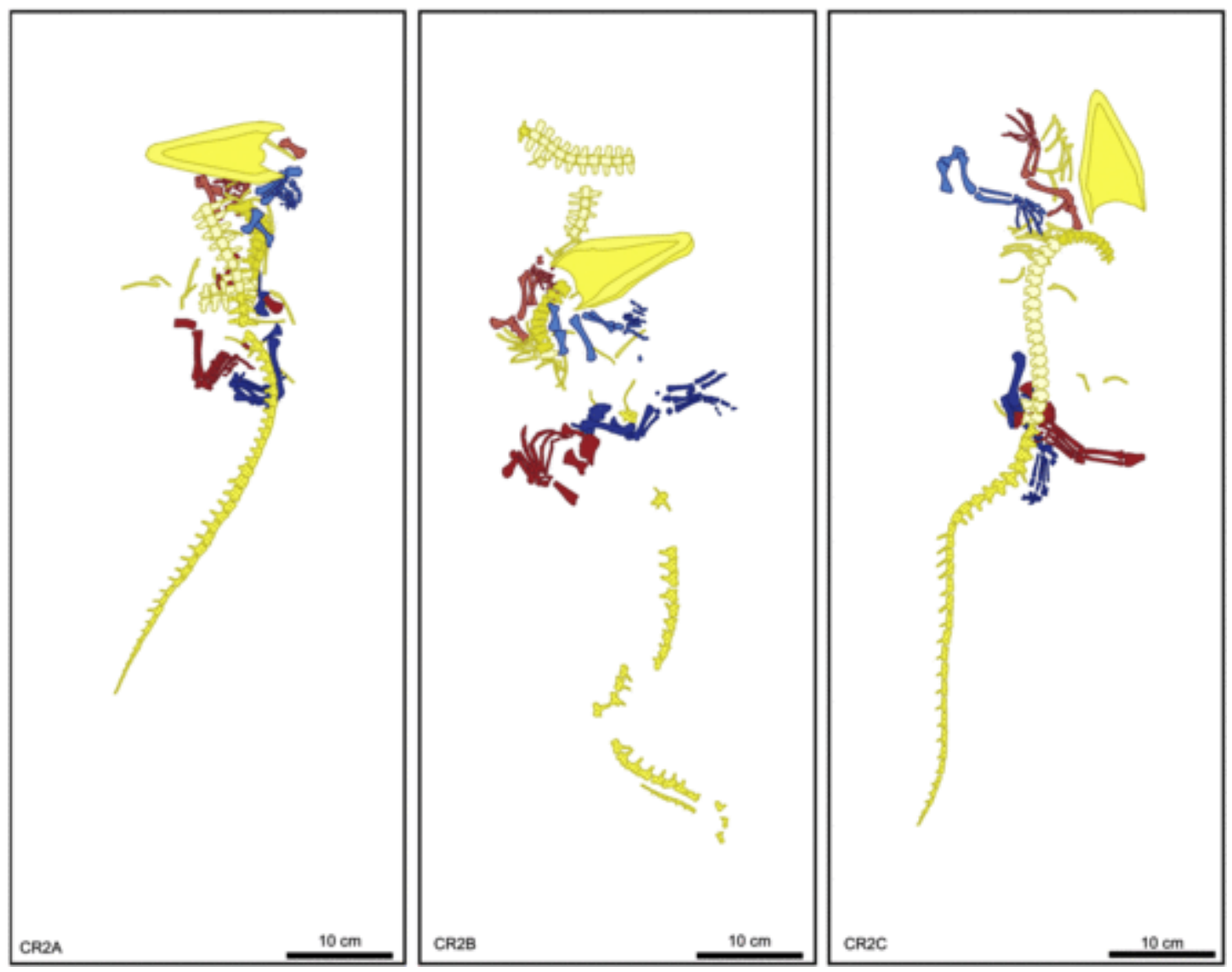

Fig. 9 Schematic outline of Treatment 2 crocodile carcass skeletal elements. All elements were drawn looking down on the carcass as it lay in the sediment, such that some element appear distorted due to parallax. The skull of each specimen was preserved ventral side up, with the mandible articulated. CR2C was the only carcass that floated lateral left surface up, and also the only carcass from Treatment 2 or 3 that retained full articulation of the axial skeleton excluding the skull and mandible. A moderate degree of articulation is maintained for all the forelimb and hindlimb units, lower than that of Treatment 1 carcasses, but higher than Treatment 3 carcasses. Manual and pedal elements remained in articulation due to the presence of soft tissue at the time of burial. These skeletal configurations are representative of a floating carcass that has sunk and been buried during advanced decay. Colours in this figure relate to the key in Fig. 7, CR1A. Scale bar represents $10 \mathrm{~cm}$.

\subsubsection{Treatment 3-- subaerial and subaqueous decay, no burial}

As with Treatment 2 skeletons, and in contrast to Treatment 1 skeletons, skeletal elements of Treatments-Treatment 3 carcasses (Fig. 10) were disarticulated or partially disarticulated. Individual variation in intra- and inter-unit articulation was observed, with carcasses on average scoring lower for intra-unit articulation than Treatment 2 carcasses. The skulls of $\mathrm{CR}_{3} \mathrm{~B}$ and $\mathrm{CR}_{3} \mathrm{C}$ remained articulated with their 
mandible, both laying ventral side up. The exception was CR3A, with the mandible disarticulating from the skull, and both elements lying dorsal side up (scoring ' $\mathrm{o}$ ' for intra-unit articulation). In all three carcasses, the cervical vertebrae disarticulated from the base of the skull. The majority of prothoracic, thoracic, lumbar, and sacral vertebrate in Treatment 3 carcasses were rotated out of, but remained near to, their in-vivo positions (each carcass scoring ' 2 ' for trunk intra-unit articulation). The intra-unit articulation of caudal vertebrae varied from disarticulated to moderately articulated among all three carcasses (with intra-unit articulation scores of ' $\mathrm{O}$ ', ' 1 ', and ' 2 ' for $\mathrm{CR}_{3} \mathrm{~A}, \mathrm{CR}_{3} \mathrm{~B}$, and $\mathrm{CR}_{3} \mathrm{C}$ respectively). Among all three carcasses, the only full inter-unit articulation maintained was between the trunk and tail for $\mathrm{CR}_{3} \mathrm{C}$. Partial inter-unit articulation was noted between the neck and trunk in all three carcasses, the trunk and tail in $\mathrm{CR}_{3} \mathrm{~A}$ and $\mathrm{CR}_{3} \mathrm{~B}$, and the left hindlimb and trunk of CR3A. Disarticulation was observed between all other units in all three carcasses. Treatment 2 and 3 carcasses were most similar in intra-unit articulation for ribs (scoring ' $\mathrm{O}$ '), and inter-unit articulation for left and right forelimb_- trunk (with disarticulation between all excluding the left hindlimb of CR3A) (see Tables 4 and 5). Similar to Treatment 2, Treatment 3 carcass forelimbs and hindlimbs disarticulated at the shoulder and hip joint, respectively. On average, the manus, pedes and caudal vertebrae of Treatment 3 carcasses had relatively lower intra-unit articulation scores than in Treatment 2 carcasses. No soft tissue remained on the manus and pedes; carpals/tarsals, metacarpals/metatarsals, and digits were disarticulated, rotated, and moved out of in-vivo position. $\mathrm{CR}_{3} \mathrm{C}$ retained some intra-unit articulation in the forelimbs and hindlimbs (scoring ' 2 ' for both forelimbs, and ' 1 ' for both hindlimbs), whereas $\mathrm{CR}_{3} \mathrm{~A}$ and $\mathrm{CR}_{3} \mathrm{C}$ suffered greater degrees of disarticulation (with scores of ' 1 ' for the hindlimbs of $\mathrm{CR}_{3} \mathrm{~A}$, and ' $\mathrm{O}$ ' for the forelimbs of $\mathrm{CR}_{3} \mathrm{~A}$ and all limbs in $\left.\mathrm{CR}_{3} \mathrm{C}\right)$. For those limbs that retained some articulation, $\mathrm{CR}_{3} \mathrm{~A}$ showed flexion at the right hindlimb tarsus, and extension at the left hindlimb knee, and $\mathrm{CR}_{3} \mathrm{C}$ showed flexion of the right forelimb at the elbow, flexion of the right hindlimb at the knee and tarsus, and extension of the left hindlimb knee and tarsus. Limb articulation patterns on average were mirrored between the left and right sides of each individual; when the left forelimb or hindlimb was articulated, so was the right forelimb or hindlimb. 

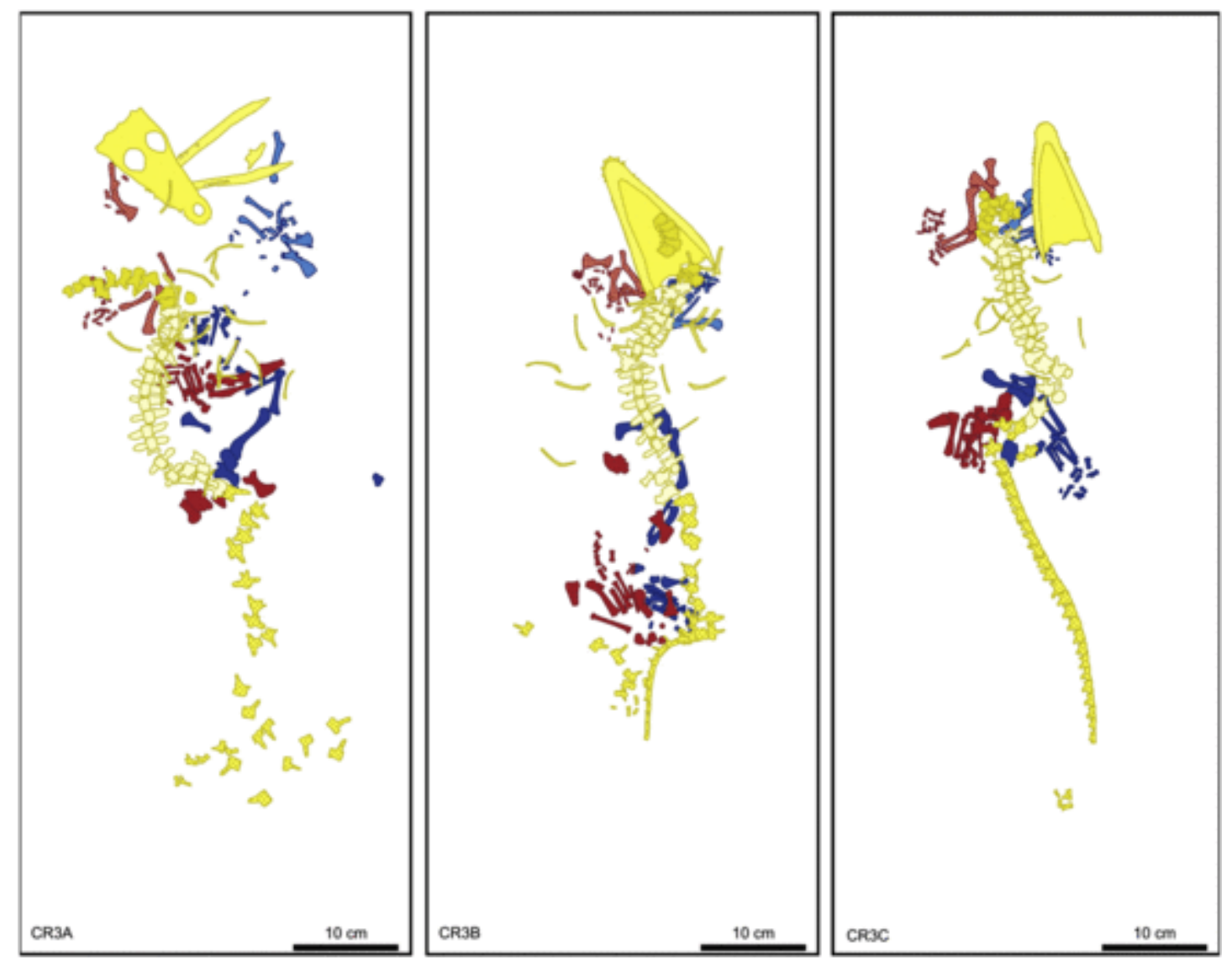

Fig. 10 Schematic outline of Treatment 3 crocodile carcass skeletal elements. All elements were drawn looking down on the carcass as it lay in the sediment, such that some elementelements appear distorted due to parallax. The disarticulated skull and mandible of $\mathrm{CR}_{3} \mathrm{~A}$ lay dorsal side up, whereas for $\mathrm{CR}_{3} \mathrm{~B}$ and $\mathrm{CR}_{3} \mathrm{C}$ they remain articulated and ventral side up. Treatment 3 carcasses showed higher degrees of disarticulation than Treatment 2 carcasses due to the continued loss of soft tissue that in turn allowed for rotation of axial skeletal elements and movement of smaller phalangeal elements. This was due to extensive soft tissue decay and the lack of burial medium that might otherwise restrict movement of skeletal elements. These skeletal configurations are representative of a floating carcass that has sunk with decay progressing to the remains stage. Colours in this figure relate to the key in Fig. 7, CR1A. Scale bar represents $10 \mathrm{~cm}$.

\section{Discussion}

This experiment has demonstrated that juvenile Crocodylus porosuscarcasses decomposing in undisturbed fresh water progress through the five recognizable stages of vertebrate decay (fresh, bloated, active decay, advanced decay and remains), reaching the final stage on average 55 days post-mortem. Based on the results of this experiment, we can conclude that preservation of articulated skeletons of extant $C$. porosus is more likely to result from 'rapid burial', that is, burial during 
the fresh stage, and less likely to result from decay in a low-energy aqueous environment or burial during the advanced decay stage. The degree of articulation that we observed in different treatments related to the amount of soft tissue still present and holding skeletal elements in place, which in turn was related to the decay stage that the carcass was in. Floating was found to be integral to the disarticulation process: not only did it provide terrestrial micro-scavengers with access to soft tissue, but also enabled endogenous and exogenous soft tissue decay to progress to a point where, upon sinking, gravitational forces forced bones out of their in-vivo position as the parts of the carcass settled on the substrate. It is pertinent to note that the timeframes discussed herein are based on a 'best case' scenario for juvenile $C$. porosus, as the experiment took place in a cool, low energy pool of fresh water (average temperature of $22.1{ }^{\circ} \mathrm{C}$ with daily temperatures fluctuating between 18and $27^{\circ} \mathrm{C}$, and initial average water parameters of $\mathrm{pH} 7.65$, salinity $0.24 \mathrm{ppt}$, and DO 92.2\%), with limited solar radiation, no macro-scavenging, and minimal aquatic micro-scavenging. The results are therefore interpreted to represent maximum possible times for each decay stage for juvenile $C$. porosus, and under the specified environmental parameters. Increases in erosional forces, or faunal interactions such as terrestrial or aquatic macro- and micro-scavenging would likely decrease the time taken to decay and disarticulate, and increase the degree of disarticulation suffered.

C.Crocodylus porosus carcasses floated to the surface of the water on average four days post-mortem due to the build-up of putrefaction gases in the digestive tract during the bloated stage. Floating carcasses did not start to sink immediately after gases started to escape via the mouth, cloaca, and right hindlimb surgical wound, or even after larval insects penetrated the intestinal and stomach walls during the active decay and advanced decay stages. Although bloat might be responsible for the carcass initially floating, the end of the bloated stage did not coincide with the end of the float time. Anderson and Hobischak (2004)similarly noted that pig carcasses in aquatic settings could float for weeks due to trapped pockets of intestinal gas, which was not to be confused with 'true' bloat where the integrity of the stomach and intestinal walls have not been disrupted, and gases have not been released through natural orifices. We noted that the white foam forming around carcass orifices and the right hindlimb surgical wounds was indicative of the release of some endogenous gas, but conclude that some gases must have remained trapped in the intestinal tract which allowed the $C$. porosus carcasses to continue floating after the bloat stage ended. The degree of saturation of soft tissue may also affect flotation time: as water enters the carcass either through intact epidermal and dermal layers that are 
permeable to water or disrupted epidermal and dermal layers, it will fill interstitial spaces in bone and displace endogenous gases in soft tissue. This will increase the overall density of the carcass, and if its density becomes greater than that of water, the carcass will sink.

While the C.Crocodylus porosus carcasses floated, the majority of skeletal elements stayed articulated or partially articulated within the still intact epidermis and dermis. This phenomenon has been observed in small lizards (Brand et al., 2003b), and large marine mammals (Schafer and Craig, 1972), and has been attributed to the presence of skin with relatively high durability and low permeability (Brand et al., 2003b; Cambra-Moo et al., 2008). Brand et al. (2003, pg 32) postulated that this could lead to misinterpretation of the fossil record, where articulation is maintained upon sinking and burial, and mistakenly attributed to rapid burial while the carcass was in the fresh stage. However, we observed that after the Treatment 2 and Treatment 3 carcasses sank 55 days post-mortem, most of the axial skeleton, forelimbs, and hindlimbs were either partially articulated or disarticulated. Although the dermis in floating carcasses maintained enough integrity to hold skeletal elements together, it was relatively weak and allowed movement of skeletal elements when gravitational forces were applied upon contact with the substrate during sinking. The lateral profile of the carcasses while floating took on an inverted ' $U$ '-shape, which would have increased the gravitational forces applied on the skeletons upon sinking. Only the buried carcasses of Treatment 1 maintained full articulation retaining their pre-burial, in-vivo skeletal configurations, due to the presence of soft tissue (primarily tendons, ligaments and skin) at the time of burial, and support from the surrounding burial medium restricting vertical and lateral movement. The high degree of inter--and intra-unit articulation seen in Treatment 1 carcasses is indicative of burial during the fresh stage, and in this experiment could not be misinterpreted as a result of prolonged decay in a low-energy aquatic environment.

The variation in the degree of articulation that was observed between Treatments 2 and 3 is likely attributable to three factors. Firstly, variation in gut flora per individual may have led to changes in gas by-product production rates and resulting variable 'bloat and float' times, which in turn may have affected the length of time aerial scavengers had access to carcasses and the extent to which soft tissue decay progressed up to the time of sinking. Secondly, the orientation and position of each floating carcass changed the availability of orifices and wounds to aerial scavengers: for example, the complete articulation of the axial skeleton (excluding 
the skull) observed for CR2C was most likely a result of the carcass floating left side up, prohibiting flying insects access to the cloaca and therefore the bones of the pelvic girdle. Thirdly, and in our opinion, most importantly, Treatment 2 carcasses were buried during the advanced decay stage when some soft tissue was still intact, especially on the manus and pedes - _ a phenomenon also noted by Richter and Wuttke (2012) for iguanid decay in fresh water-_ whereas Treatment 3 carcasses suffered continued soft tissue decay in water leading to the eventual collapse, rotation, and separation of skeletal elements during the remains decay stage. While Treatment 2 carcasses retained some dermal integrity on the manus and pedes, allowing for preservation of full to moderate articulation upon burial, the Treatment 3 carcasses suffered loss of soft tissue holding the skeletal elements of the manus and pedes in place due to prolonged subaqueous decay, allowing for their disarticulation. Treatment 2 carcasses had adipocere present beside the caudal vertebrae, allowing for the preservation of articulation prior to burial. Prolonged subaqueous exposure led to the eventual dissolution of caudal adipocere in Treatment 3 carcasses. Therefore, patterns of articulation seen in Treatment 2 carcasses are indicative of burial during the advanced decay stage. Specifically, disarticulation of the head from the neck and the limbs from the trunk, along with moderate articulation to disarticulation of skeletal elements within the axial skeleton, combined with moderate to full intra-unit articulation scores (' 2 ' to ' 4 ') for fore- and hindlimbs, including retention of manual and pedal articulation. Further disarticulation of the fore--and hindlimb including the manual and pedal elements, as was seen in Treatment 3 carcasses, is indicative of burial during the remains decay stage when further soft tissue decay has occurred. Even though the degree of articulation differed between individual carcasses within each treatment, patterns of limb articulation were on average mirrored between the left and right side within each carcass. It would therefore also seem reasonable to assume that a fossil with disparate articulation between paired limbs had suffered non-necrolytic pre-, peri-, or postmortem soft tissue trauma.

Disarticulation of vertebrate carcasses in low-energy freshwater settings as seen in our experiment has also been observed in other experiments: both for multiple goldfish carcasses (Hellawell and Orr, 2012) and a single iguanid (Oplurus cuvieri) carcass (Richter and Wuttke, 2012). Hellawell and Orr (2012) found that skeletal disarticulation of goldfish occurred in shallow fresh water in petri dishes in the absence of any outside disturbance. They concluded that decay in a low-energy aqueous environment did not account for the high levels of articulation seen in fossil 
fish of the Green River Formation (Hellawell and Orr, 2012). InRichter and Wuttke's (2012) freshwater decay experiment of one iguanid carcass, they conclude that while some disarticulation may have resulted from the withdrawal of the carcass multiple times for X-radiographs over a 2-month period, the majority of disarticulation occurred in the absence of outside disturbance. We, too, similarly conclude that in the absence of any outside disturbance, disarticulation of skeletal elements in an aqueous setting can occur.Richter and Wuttke (2012) also observed that the iguanid fore- and hindlimbs separated from the axial skeleton but remained articulated within each limb: as per the terminology used in our study, this would be classified as full intra-unit articulation and inter-unit disarticulation. We observed a similar pattern of high intra-unit articulation scores for the fore---and hindlimbs of our Treatment 2C.Crocodylus porosus carcasses along with inter-unit disarticulation, and attribute this to the presence of soft tissue along the length of the forelimbs and hindlimbs holding skeletal elements in place prior to burial.

The results of this study suggest that if a carcass is inhibited from floating, the likelihood of articulated preservation increases. Rapid burial is one such way to inhibit floating, as demonstrated by Treatment 1 carcasses, although for one carcass (CR1B) 'bloat and float' still occurred even after burial under a $20 \mathrm{~cm}$ layer of noncompacted fine-grained sand. Therefore, burial would not only have to be rapid enough to occur before the bloated stage commenced (approximately before 4 days post-mortem for juvenile C.Crocodylus porosus carcasses), it would also have to involve enough sediment to continue to negate the positive buoyancy created by internal gas production. However, rapid burial may not be the only avenue for inhibition of floating: (1) bloat could still occur with floating prohibited by physical barriers, such as might occur if a carcass became trapped under a log jam or jumble of vegetation (see crocodile carcasses trapped under logs in Weigelt, 1989, Plates 27 and 30), (2) the carcass might pass through the bloat period in a terrestrial setting, then may either be covered with water and sediment in-situ, or be transported into a body of water and buried (as has been proposed for the holotype Susisuchus anatoceps by Salisbury et al., 2003); (3) bloat not occurring due to species specific anatomical and physiological characteristics (Schoener and Schoener, 1984; Brand et al., 2003b; Reisdorf and Wuttke, 2012)__ but we are unsure as to what these might be or if there are any examples of taxa in which floating is not known to occur _ _ or (4) low water temperatures reducing gas production (Elder and Smith, 1984; Elder et al., 1988). Any of these scenarios that do not invoke rapid burial as the cause of articulated preservation must inhibit the access of aerial or aqueous macro- 
scavenger to the carcass. Scenario (1) could occur in tandem with 'rapid burial', extending the amount of time needed to sufficiently weigh a carcass down with sediment. Skeletal elements in a Scenario (2) carcass could be buried in a flood plain or riverbank under a relatively thin amount of sediment, initially in an aquatic setting, but with water levels receding and reducing water in interstitial spaces in the sand during the bloat stage. If a carcass underwent bloat unburied in a terrestrial setting to be later buried in an aquatic setting, the carcass would retain some intact soft tissue to avoid disarticulation during water and sediment influx in-situ, or transport to the final burial site. Scenario (3) would not require 'rapid burial', as the carcass would not float and disarticulate on sinking; however, soft tissue trauma would increase the likelihood of disarticulation occurring. In relation to Scenario (4), Elder et al. (1988) and Elder and Smith (1984) propose that water temperature controls the production of gases internally and the resulting buoyancy of a decaying carcass, with cooler temperatures (below $16^{\circ} \mathrm{C}$ ) limiting flotation of fish carcasses. In our experiment, carcasses began to float on days 5 to 7 (22nd-_24th of September) when water temperature ranged between $21.2{ }^{\circ} \mathrm{C}$ and $23.6{ }^{\circ} \mathrm{C}$ with an average temperature of $22{ }^{\circ} \mathrm{C}$ (see Fig. 2), so it appears that the minimum fresh water temperature which still allow for juvenile $C$. porosus carcasses to float is at least $22{ }^{\circ} \mathrm{C}$. It is feasible that lower water temperatures could have the same flotation inhibition effect on crocodyliform carcasses.

Using Crocodylus porosus decay patterns as an analogue for extinct crocodyliform decay patterns, it can be inferred that preservation of high intra- and inter-unit articulation in fossil crocodyliforms preserved in fresh water sediments was a result of the inhibition of floating via burial during the fresh stage, trapping under physical barriers, removal from water, or enough trauma to prevent bloat (under our experimental conditions, for juvenile $C$. porosus this would need to occur within the first week post mortem). High degrees of cranial and post-cranial articulation including vertical preservation of manus and pedes, similar to that seen in Treatment 1 carcasses, would be indicative of burial during the fresh stage with soft tissue and burial medium holding skeletal elements in-vivo. A lack of pelvic girdle elements in fossil crocodyliforms would be expected for carcasses of juvenile animals (with only partially fused joints between the ilia and sacral ribs) that floated during decay and that were buried only after sinking (seeSalisbury et al., 2003). Those that show vertical preservation of disarticulated portions of the axial or appendicular skeleton, especially the manus and pedes (resembling that of CR2A), were likely to have been buried during advanced decay upon sinking (for juvenile $C$. 
porosus, approximately three to eight weeks post mortem), with higher degree of articulation in the manus and pedes resulting from burial with manual and pedal soft tissue still intact. High degrees of articulation between caudal vertebrae could result from the presence of adipocere prior to burial, given that many species of extant crocodylians typically have large adipose tissue deposits medial to both the epaxial and hypaxial muscle masses in the base of the tail (Gadow, 1882; Frey, 1988a). Those that have a greater degree of disarticulation of the forelimbs and hind limbs, especially skeletal elements of the manus, pedes, and tail, are most likely indicative of carcasses having reached the remains decay stage (for juvenile $C$. porosus, greater than approximately eight weeks post-mortem) prior to burial, where extensive subaqueous soft tissue decay has occurred. Disparate articulation in paired limbs would therefore be indicative of pre-, peri-, or post-mortem soft tissue trauma excluding necrolysis and micro-scavenging. In $C$. porosus, as occurs in all other extant crocodylians, the osteoderms that form part of the dorsal shield (paravertebral shield + accessory osteoderms) sit within the corium, with sagitally adjoining osteoderms bound together via interosteoderm ligaments (Schmidt, 1914; Frey, 1988a). In many taxa, laterally adjoining dorsal osteoderms are also joined to each other by serrated sutures (Frey, 1988a; Salisbury and Frey, 2001); but we note that such joints to not occur in $C$. porosus, which has very reduced dorsal osteoderms relative to other extant taxa. These interosteodermal joints (interosteodermal ligaments and interosteodermal sutures) could result in groups of articulated osteoderms detaching during decay and becoming preserving as intact sections. Although osteoderms were not observed in their in-vivo positions for the juvenile $C$. porosus carcasses at the end of the experiment, the additional tight tendinous integration of the paravertebral shield with the vertebral column of the trunk and tail base via the epaxial musculature (see Frey, 1988a,b; Salisbury and Frey, 2001) could result in the additional maintenance of anatomical coherence of these parts of the trunk skeleton until after the carcass has sunk; this is not true for the cervical and more terminal caudal vertebrae, which are not tightly as integrated with the dermis and epaxial musculature_(see Frey, 1988a,b; Salisbury and Frey, 2001). In our experiment, the vertebral column of each carcass remained articulated during floating, with only two specimens suffering vertebral disarticulation upon sinking (CR2A and CR2B); even so, the vertebral column separated into articulated sections, demonstrating some remaining anatomical coherence between sections of the vertebral column and the epaxial musculature. 
The need to inhibit floating in order to maintain skeletal articulation must also be taken into account when considering the taphonomic histories of vertebrate fossils associated with Lagerstätten. Articulation of skeletal elements and preservation of soft tissues in Lagerstätten fossils are thought to have resulted from carcasses in good condition decaying in low energy aquatic environments that are anoxic, acidic or hypersaline, all of which limit opportunities for scavenging and destruction of soft tissue (Allison, 1988; Allison and Briggs, 1991; Taylor, 1995; Behrensmeyer et al., 2000). Although rapid or catastrophic burial can form Lagerstätten, other 'stagnation' mechanisms can also result in the formation of Lagerstätten, such as (1) sinking into a soupy substrate (Smith and Wuttke, 2012), (2) microbial mat formation (Hellawell and Orr, 2012; Schwermann et al., 2012; Iniesto et al., 2013), and (3) adipocere formation (O'Brien and Kuehner, 2007; Ubelaker and Zarenko, 2011; Schwermann et al., 2012). However, these stagnation scenarios do not account for the likelihood that even in low energy conditions, vertebrate carcasses may float and then disarticulate upon sinking. And even after sinking, prolonged subaqueous decay prior to burial might still allow for partial or total disarticulation. For example, in our experiment, adipocere formed along the caudal vertebrae of the juvenileCrocodylus porosus, but those left to decay subaqueously (Treatment 3) still suffered disarticulation of caudal elements. In future taphonomic analyses, assumptions that involve any of these four mechanisms must also take into account processes that stop carcasses floating, or that reduce flotation time such that the carcass sinks immediately at the end of the bloat stage, or in the early stages of active decay, before extensive soft tissue decay and skeletal disarticulation can occur.

\section{Acknowledgements}

The authors thank Amelia Cook (The University of Queensland) for her assistance during the actualistic decay experiment. We also thank Andrew C Barnes (The University of Queensland) for the generous loan of experimental equipment. The research was supported by an Australian Postgraduate Award (The University of Queensland, to CES), with additional funds from The University of Queensland and Longreach Regional Council (to SWS). The research was completed in accordance to The University of Queensland Animal Ethic Committee (AEC approval number SBS/015/11) and the Queensland Environmental Protection Authority (scientific purposes permit WISP05816009).

\section{References}


Abdel-Maksoud G. and Abdel-Hady M., Effect of burial environment on crocodile bones from Hawara excavation, Fayoum, Egypt, J. Cult. Herit. 12, 2011,180-189.

Allison P.A., Konservat-Lagerstätten: cause and classification,Paleobiology 14, 1988, 331344 .

Allison P.A. and Briggs D.E.G., Taphonomy of non-mineralized tissues, In: AllisonP.A. and Briggs D.E.G., (Eds.), Taphonomy: Releasing the Data Locked in the Fossil Record, 1991, Plenum Press; New York, 26-70.

Allison P.A., Smith C.R., Kukert H., Deming J.W. and Bennett B.A., Deep-water taphonomy of vertebrate carcasses: a whale skeleton in the bathyal Santa Catalina Basin, Paleobiology 17, 1991, 78-89.

Anderson G.S. and Hobischak N.R., Decomposition of carrion in the marine environment in British Columbia Canada, Int. J. Legal Med. 118, 2004,206-209.

Beardmore S.R., Orr P.J., Manzocchi T. and Furrer H., Float or sink: modelling the taphonomic pathway of marine crocodiles (Mesoeucrocodylia, Thalattosuchia) during the death-burial interval, Palaeobiodivers. Palaeoenviron. 92, 2012a, 83-98.

Beardmore S.R., Orr P.J., Manzocchi T., Furrer H. and Johnson C., Death, decay and disarticulation: modelling the skeletal taphonomy of marine reptiles demonstrated using Serpianosaurus (Reptilia; Sauropterygia), Palaeogeogr. Palaeoclimatol. Palaeoecol. 337-338, 2012b, 1-13.

Behrensmeyer A.K. and Miller J.H., Building links between ecology and paleontology using taphonomic studies of recent vertebrate communities, In:Louys J., (Ed), Paleontology in Ecology and Conservation, 2012, Springer Berlin Heidelberg; Berlin, Heidelberg, 69-91.

Behrensmeyer A.K., Kidwell S.M. and Gastaldo R.A., Taphonomy and paleobiology, Paleobiology 26, 2000, 103-147.

Benton M.J. and Clark J.M., Archosaur phylogeny and the relationships of the Crocodilia, In: Benton M.J., (Ed), The Phylogeny and Classification of Tetrapods. Systematics Association Special Volume No. 35A, 1988,Clarendon Press; Oxford, 295-338.

Bornemissza G.F., An analysis of arthropod succession in carrion and the effect of its decomposition on the soil fauna, Aust. J. Zool. 5, 1957, 1-12.

Brand L.R., Hussey M. and Taylor J., Taphonomy of freshwater turtles: decay and disarticulation in controlled experiments, J. Taphon. 1, 2003a, 233-245. 
Brand L.R., Hussey M. and Taylor J., Decay and disarticulation of small vertebrates in controlled experiments, J. Taphon. 1, 2003b, 69-95.

Brasier M.D., Wacey D. and Mcloughlin N., Taphonomy in temporally unique settings: an environmental traverse in search of the earliest life on earth, In:Allison P.A. and Bottjer D.J., (Eds.), Taphonomy: Process and Bias Through Time, 2011, Springer Netherlands; Dordrecht, 488-518.

Brochu C.A., Ontogeny of the Postcranium in Crocodylomorph Archosaurs, 1992,University of Texas; Austin.

Buffetaut E., Radiation évolutive, paléoécologie et biogéographie des Crocodiliens mésosuchiens, Mém. Soc. géol. Fr. 6o, 1982, 1-88.

Cambra-Moo O., Buscalioni Á.D. and Delgado-Buscalioni R., An approach to the study of variations in early stages of Gallus gallus decomposition, J. Taphon. 6, 2008, 21-40.

Clark J.M., Patterns of evolution in Mesozoic crocodyliformes, In: Fraser N.C. andSues H.D., (Eds.), In the Shadow of the Dinosaurs, 1994, Cambridge University Press; New York, 84-97.

Cooper J., Methods in herpetological forensic work — post-mortem techniques,Appl. Herpetol. 5, 2008, 351-370.

Cruz I., Avian taphonomy: observations at two Magellanic penguin (Spheniscus magellanicus) breeding colonies and their implications for the fossil record, $J$. Archaeol. Sci. 34, 2007, 1252-1261.

Davis P.G. and Briggs D.E.G., The impact of decay and disarticulation on the preservation of fossil birds, Palaios 13, 1998, 3-13.

De Araújo H.I. and da Silva Marinho T., Taphonomy of a Baurusuchus(Crocodyliformes, Baurusuchidae) from the Adamantina Formation (Upper Cretaceous, Bauru Basin), Brazil: implications for preservational modes, time resolution and paleoecology, $J$. South Amer. Earth Sci. 47, 2013, 90-99.

Denys C., Taphonomy and experimentation, Archaeometry 44, 2002, 469-484.

Elder R.L., Principles of Aquatic Taphonomy With Examples From the Fossil Record, 1985, The University of Michigan.

Elder R.L. and Smith G.R., Fish taphonomy and paleoecology, Geobios Special Me 287291, 1984.

Elder R.L., Smith G.R. and Arbor A., Fish taphonomy and environmental inference in paleolimnology, Palaeogeogr. Palaeoclimatol. Palaeoecol. 62, 1988,577-592. 
Faux C.M. and Padian K., The opisthotonic posture of vertebrate skeletons: postmortem contraction or death throes?, Paleobiology 33, 2007, 201-226.

Frey EE., Anatomie des Körperstammes von Alligator mississippiensis Daudin,[Anatomy of the body stem of Alligator mississippiensis Daudin], Stuttg. Beitr. Naturkunde A 424, 1988a, 1-106.

Frey EE., Das Tragsystem der Krokodile-_- eine biomechanische und phylogeneitische Analyse, [The carrying system of crocodilian: a biomechanical and phylogenetic analysis], Stuttg. Beitr. Naturkunde A 426, 1988b, 1-6o.

Frye F.L., Methods in herpetological forensic work - sampling and standard laboratory techniques, Appl. Herpetol. 5, 2008, 339-350.

Gadow H., Untersuchungen über die Bauchmuskeln der Krokodile, Eideschsen und Schildkröten, Gegenbaurs Morphol. Jahrb. 7, 1882, 57-100.

Gifford D.P., Taphonomy and paleoecology: a critical review of archaeology ${ }_{-1}^{\prime \prime}$ sister disciplines, Adv. Archaeol. Method Theory 4, 1981, 365-438.

Gifford-Gonzalez D., Bones are not enough: analogues, knowledge, and interpretive strategies in zooarchaeology, J. Anthropol. Archaeol. 10, 1991,215-254.

Grange D.R. and Benton M.J., Kimmeridgian metriorhynchid crocodiles from England, Palaeontology 39, 1996, 497-514.

Hellawell J. and Orr P.J., Deciphering taphonomic processes in the Eocene Green River Formation of Wyoming, Palaeobiodivers. Palaeoenviron. 92, 2012,353-365.

Iniesto M., Lopez-Archilla a. Ia.I., Fregenal-Martinez Mㅆ., Buscalioni a. D.a.D.and Guerrero M.C., Involvement of microbial mats in delayed decay: an experimental essay on fish preservation, Palaios 28, 2013, 56-66.

Klein N., Scheyer T. and Tütken T., Skeletochronology and isotopic analysis of a captive individual of Alligator mississippiensis Daudin, 1802, Foss. Rec. 12, 2009, 121-131.

Kuhn OO., Fossilium Catalogus I: Animalia, Pars 75: Crocodilia, 1936, Gravenhage.

Markwick P.J., Crocodilian diversity in space and time: the role of climate in paleoecology and its implication for understanding K/T extinctions, Paleobiology 24, 1998, 470497.

Meyer C.A., Burial experiments with marine turtle carcasses and their paleoecological significance, 6, 2012, 89-96. 
Nelder M.P., McCreadie J.W. and Major C.S., Blow flies visiting decaying alligators: is succession synchronous or asynchronous?, Psyche (Camb Mass) 2009, 2009, 1-7.

Noto C.R., The Influence of Post-burial Environment and Plant__Bone Interactions on Vertebrate Preservation: An Experimental Taphonomic Study, 2009, Stony Brook University.

O'-Brien T.G. and Kuehner A.C., Waxing grave about adipocere: soft tissue change in an aquatic context, J. Forensic Sci. 52, 2007, 294-301.

O'-Flynn M.A. and Moorhouse D.E., Identification of early immature stages of some common Queensland carrion flies, Aust. J. Entomol. 19, 1980, 53-61.

Payne J.A., A summer carrion study of the baby pig Sus scrofa Linnaeus,Ecology 46, 1965, 592-602.

Peterson J.E., Experimental Taphonomy of Macrovertebrate and Microvertebrate Fossils of the Hell Creek Formation (Latest Maastrichtian) of Southeastern Montana, 2010, Northern Illinois University.

Pol D., Turner A.H. and Norell M.A., Morphology of the Late Cretaceous crocodylomorph Shamosuchus djadochtaensis and a discussion of neosuchian phylogeny as related to the origin of Eusuchia, Bull. Am. Mus. Nat.

Hist. 324, 2009, 103.

Prassack K.A., The effect of weathering on bird bone survivorship in modern and fossil saline-_alkaline lake environments, Paleobiology 37, 2011, 633-654.

Rauhut O.W.M. and Lopez-Arbarello A., Archosaur evolution during the Jurassic: a southern perspective, Rev. Asoc. Geol. Argent. 63, 2008, 557-585.

Reisdorf A.G. and Wuttke M., Re-evaluating Moodie-'s Opisthotonic-Posture hypothesis in fossil vertebrates. Part I: reptiles - the taphonomy of the bipedal dinosaurs Compsognathus longipes and Juravenator starki from the Solnhofen Archipelago (Jurassic, Germany), Palaeobiodivers. Palaeoenviron. 92, 2012, 119168.

Richter A. and Wuttke M., Analysing the taphonomy of Mesozoic lizard aggregates from Uña (eastern Spain) by X-ray controlled decay experiments,Palaeobiodivers. Palaeoenviron. 2012, (published).

Rogers R.R. and Kidwell S.M., A conceptual framework for the genesis and analysis of vertebrate skeletal concentrations, In: Rogers R.R., Eberth D.A.and Fiorillo A.R., (Eds.), Bonebeds: 
Genesis, Analysis, and Paleobiological Significance, 2007, The University of Chicago Press; Chicago, 499.

Rothschild B., Scientifically rigorous reptile and amphibian osseous pathology: lessons for forensic herpetology from comparative and paleo-pathology,Appl.

Herpetol. 6, 2009, 47-79.

Salisbury S.W. and Frey E., A biomechanical transformation model for the evolution of semi-spheroidal articulations between adjoining vertebral bodies in crocodilians, In: Grigg G.C., Seebacher F. and Franklin C.E., (Eds.),Crocodilian Biology and Evolution, 2001, Surrey Beatty \& Sons; Sydney, Australia, 85-134.

Salisbury S.W., Frey E., Martill D.M. and Buchy M.-C., A new crocodilian from the Lower Cretaceous Crato Formation of north-eastern Brazil, Palaeontogr. Abt. A 270, 2003, 3-47.

Schafer W. and Craig G.Y., Ecology and Palaeoecology of Marine Environments,1972, Oliver and Boyd.

Schmidt W.J., Studien am Integument der Reptilian. VI. Über die Knochenschuppen der Crocodile, Zool. Jahrb. 38, 1914, 643-666.

Schoener A. and Schoener T.W., Experiments on dispersal: short-term floatation of insular anoles, with a review of similar abilities in other terrestrial animals, Oecologia 63, 1984, 289-294.

Schwarz-Wings D., Klein N., Neumann C. and Resch UU., A new partial skeleton ofAlligatorellus (Crocodyliformes) associated with echinoids from the Late Jurassic (Tithonian) lithographic limestone of Kelheim, S-Germany, Foss. Rec. 14, 2011, 195205.

Schwermann A.H., Wuttke M. and Schultz J.A., Virtopsy of the controlled decomposition of a dormouse Eliomys quercinus as a tool to analyse the taphonomy of Heterohyus nanus from Messel (Eocene, Germany),Palaeobiodivers.

Palaeoenviron. 92, 2012, 29-43.

Smith K.T. and Wuttke M., From tree to shining sea: taphonomy of the arboreal lizard Geiseltaliellus maarius from Messel, Germany, Palaeobiodivers. Palaeoenviron. 2012, (published).

Steel R., Crocodylia, In: Kuhn O., (Ed), Handbuch Der Paleoherpetologie: Encyclopedia of Paleoherpetology, 1973, Gustav Fisher; Stuttgart and Portland, 16. 
Taylor J.B, A laboratory taphonomy study of vertebrates in a freshwater environment, Comp. Gen. Pharmacol, 1995, Loma Linda University.

Ubelaker D.H. and Zarenko K.M., Adipocere: what is known after over two centuries of research, Forensic Sci. Int. 208, 2011, 167-172.

Watson E.J. and Carlton C.E., Spring succession of necrophilous insects on wildlife carcasses in Louisiana, J. Med. Entomol. 40, 2003, 338-347.

Watson E. and Carlton C., Insect succession and decomposition of wildlife carcasses during fall and winter in Louisiana, J. Med. Entomol. 42, 2005,193-203.

Weigelt, J., 1989. Recent vertebrate carcasses and their paleobiological implications. (J. Schaefer, trans. from Weigelt, J., 1927. Rezente Wirbeltierleichen und ihre paläobiologische Bedeutung. Verlag von Max Weg, Leipzig, p. 227). The University of Chicago Press, Chicago, p. 188.

Young D.E., How powerful are archaeological inferences based upon experimental replication?, In: Bonnichsen R. and Sorg M.H., (Eds.), Bone Modification,1989, University of Maine Center for the Study of the First Americans;Orono, 53-60 